\title{
Foliar behaviour of biogenic semi-volatiles: potential applications in sustainable pest management
}

\author{
Adedayo O. Mofikoya ${ }^{1}$ (D) . Thuy Nga T. Bui ${ }^{1} \cdot$ Minna Kivimäenpää $^{1}$ (D) . Jarmo K. Holopainen ${ }^{1}$ (D) - Sari J. Himanen ${ }^{2}$ (D) . \\ James D. Blande ${ }^{1}$ (D)
}

Received: 4 November 2018 / Accepted: 24 January 2019 / Published online: 17 March 2019

(c) The Author(s) 2019

\begin{abstract}
Plants emit an extremely diverse bouquet of volatile organic compounds (VOCs) from their above-ground and below-ground parts. Emissions are constitutive or induced, e.g. by herbivores. VOCs can be classified as highly volatile, volatile and semivolatile compounds. Sesquiterpenes (SQTs) are typical semi-volatile organic compounds (sVOCs) released by plants. Similarly, herbivore-induced homoterpenes and methyl salicylate also have relatively low volatility. SVOCs have a high boiling point $\left(>240{ }^{\circ} \mathrm{C}\right)$ and a vapour pressure below $0.005 \mathrm{kPa}$ at $25^{\circ} \mathrm{C}$. Glandular trichomes on plant surfaces can store SQTs in mixtures with more volatile VOCs, which are released into the air by diffusion or after gland rupture. The sVOCs stored in glandular trichomes often have repellent effects on herbivores, while herbivore-induced sVOCs are known for their attractiveness to natural enemies of herbivores, i.e. they act in indirect chemical defence of plants. Due to their low volatility, sVOCs produced by plants may easily adhere to the surfaces of emitter and neighbouring plants during the colder temperatures that plants face, e.g. at night. On the foliage of neighbouring receiver plants, sVOCs may act in direct and indirect defence of that plant species. When the temperature rises again, sVOCs are released into the atmosphere. The semi-volatile reaction products of highly volatile plant monoterpenes and photochemical pollutants such as ozone could constitute further sVOCs on plant leaf surfaces. Here, we review recent literature of the plant surface-environment interaction of biogenic sVOCs and particularly evaluate potential crop protection strategies such as intercropping and companion planting using sVOC-emitting species. Foliage typically forms the widest surfaces on crop plants, and foliar herbivory is a major type of pest damage during the vegetative stage of crop plants. Foliage is also a major source of herbivore-induced VOC emissions. Consequently, we focus on foliage-mediated sVOCs and their potential in pest management.
\end{abstract}

Keywords Companion plants $\cdot$ Ecosystem services $\cdot$ Herbivores $\cdot$ Plant defence $\cdot$ Secondary metabolites $\cdot$ Secondary plants

\section{Abbreviations}

DMNT (E)-3,8-dimethyl-1,4,7-nonatriene

ELVOC Extremely low volatility organic compound

GLV Green leaf volatile

GT Glandular trichome

IVOC Intermediate volatility organic compound

Handling Editor: Dagmar Voigt.

Jarmo K. Holopainen

jarmo.holopainen@uef.fi

1 Department of Environmental and Biological Sciences, University of Eastern Finland, P.O. Box 1627,

70211 Kuopio, Finland

2 Natural Resources Institute Finland (Luke), Natural Resources, Plant Health, Lönnrotinkatu 7, 50100 Mikkeli, Finland
LVOC Low volatility organic compound

MeSA Methyl salicylate

MT Monoterpene

SQT Sesquiterpene

sVOC Semi-volatile organic compound

SOA Secondary organic aerosol

TMTT (E,E)-4,8,12-trimethyltrideca-1,3,7,11-tetraene

VOC Volatile organic compound

\section{Introduction}

A better knowledge and appreciation of the ecological interactions between plants and associated biota and the trophic cascades that take place in agroecosystems is a requirement for sustainable and more climate-resilient food production and food security under changing climatic conditions 
Fig. 1 Glandular trichomes (GT) of a basil (Ocimum basilicum, cv. Dolly) and c, d Rhododendron tomentosum. a-c Scanning electron microscopy of air-dried samples, d light microscopy of chemically fixed sample. GT of basil are sunken in the epidermis (a), GT of $R$. tomentosum raised above the epidermis on a stalk (black arrows in $\mathbf{b}$, d). Heads of GTs are divided into compartments (white rhombi in a, c, d) which act in storage of secondary metabolites. c Exudates (white asterisk) released from the head of an $R$. tomentosum GT. d Structures of the GT have started to deteriorate, and synthesis cells for secondary metabolites cannot be identified

(Tilman et al. 2002; Francis et al. 2003; Haddad et al. 2011; Altieri et al. 2012; Giron et al. 2018). Comprehensive understanding of the agroecology of cropping systems can help to buffer for biotic and abiotic stressors and potentiate ecological intensification of crop production (Altieri et al. 2012; Kovacs-Hostyanszki et al. 2017). Ecological intensification of agricultural production means producing more crop yield with less external and environmentally critical inputs, and one move towards this goal is a shift from monocultures to more crop-diverse agroecosystems where the important role of companion/secondary plants is considered, e.g. in biocontrol of insect pests (Parolin et al. 2012). Ecological intensification also involves active field ecosystem management to increase the intensity of the ecological processes that support production and maintain ecosystem services such as nutrient cycling, biotic pest regulation, and pollination (Kovacs-Hostyanszki et al. 2017). Combining these individual components of functional biodiversity of agroecosystems with understanding of their role for several ecosystem services supported by modern biotechnology and information technology is also called "ecostacking" (Hokkanen and Menzler-Hokkanen 2018). Traditionally, crop plants have been cultivated in mixtures of several species or cultivars of crops which stabilises yields over the long term, but also promotes diversity of the agroecosystem (Altieri et al. 2012). For maintenance of pollinators and natural enemies of insect pests, flowering intercrops and some flowering, companion weeds can help to increase the diversity of field vegetation and positively affect crop development (Ninkovic et al. 2016). Designing pest-buffered cropping needs to combine knowledge of pest biology, including their natural enemies and their responsiveness to host location cues and crop defences. While the term "secondary plant" is mostly used in field associations, "companion plant" is used in experimental cases, when the plant is mostly considered as an "emitter plant".

Volatile organic compounds (VOCs) are produced by all plant parts, although humans mostly sense the distinctive strong and pleasant floral scents of pollinator-attracting flowers (Borghi et al. 2017). In flowers and roots, VOCs are primarily produced in epidermal cells (Adebesin et al. 2017), such as flower petals (Kolosova et al. 2001) from which they are directly released into the atmosphere. In leaves,
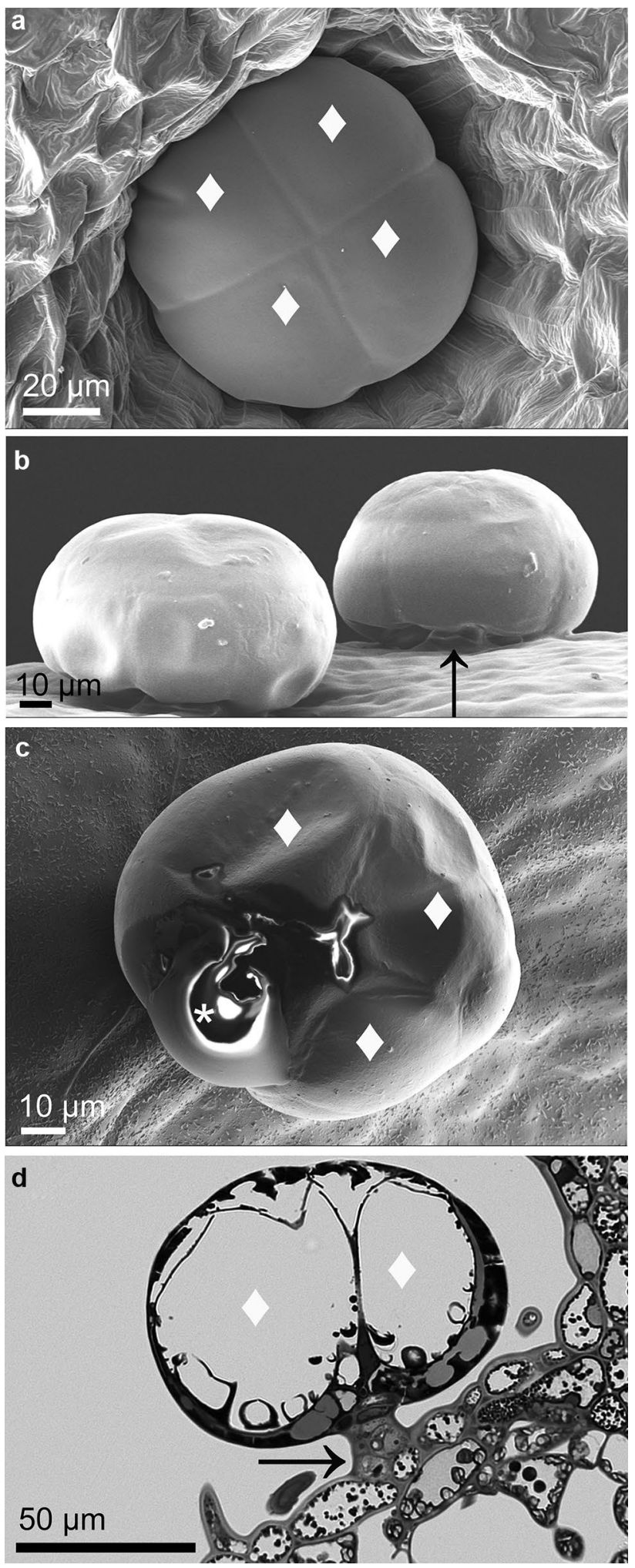

synthesis of VOCs can take place in mesophyll cells with release through the stomata or cuticle (Loreto and Schnitzler 2010) or from glandular trichomes (GTs) on the leaf surface. GTs (Figs. 1, 2a) are found mostly on leaves (Tissier 

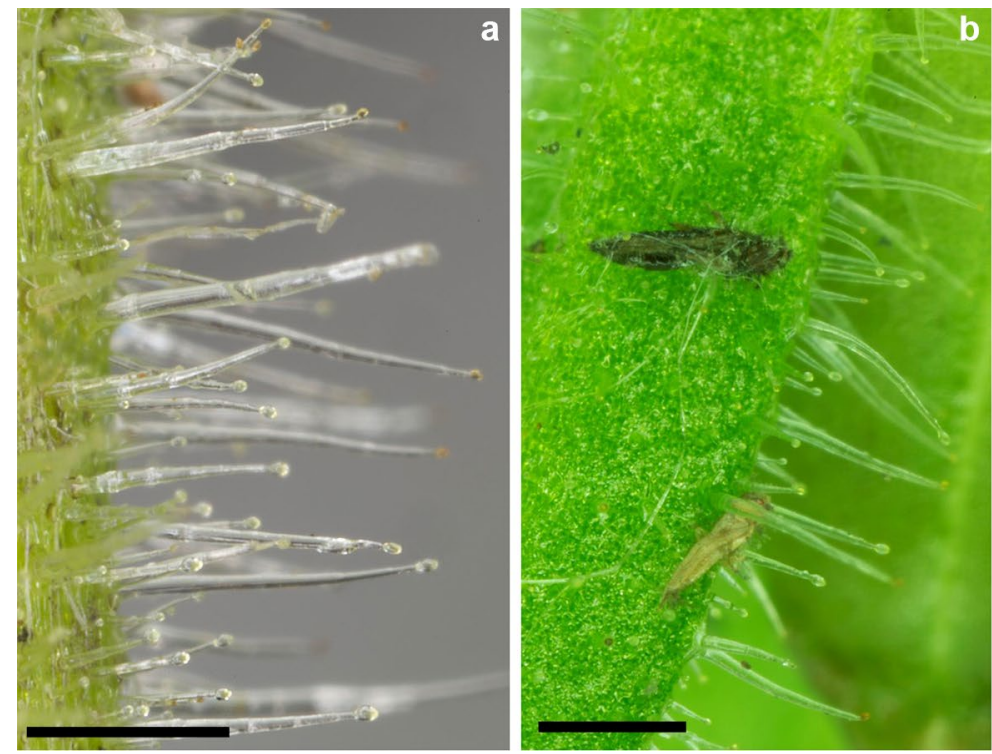

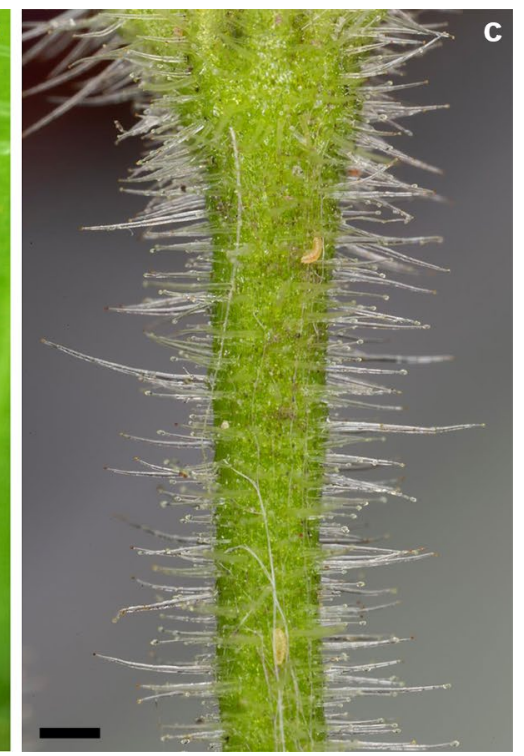

Fig. 2 Details of short-stalked and long-stalked capitate glandular trichomes on Petunia $\times$ hybrida cv. Night sky and insects entrapped by trichomes. a Short-stalked and long-stalked capitate trichomes on stem, b dead thrips on inflorescence trichomes, $\mathbf{c}$ dead species of Diptera larvae captured by/stuck to inflorescence trichomes. Bar $=0.5 \mathrm{~mm}$ in all figures et al. 2017; Niinemets 2018) but are also present on stems (Mofikoya et al. 2018a, b), buds (Mofikoya et al. 2018a, b) and flower bracts (Muravnik et al. 2016). Furthermore, insects from several insect families are also capable of producing similar VOCs to those produced by plants, including benzenoids, monoterpenes (MTs) and sesquiterpenes (SQTs) mostly as aggregation, sex and alarm pheromones (Schiestl 2010; Pickett and Khan 2016). VOCs play an important role in plant-plant interactions (Heil 2014; Yoneya and Takabayashi 2014) and in communication with other organisms in the ecosystem (Blande et al. 2014; Stenberg et al. 2015). Volatility of VOCs is variable depending on the chemical properties of each compound. VOCs are normally emitted in a temperature-dependent way at normal air pressure (760 $\mathrm{mmHg}$ ); higher temperatures lead to a more rapid shift from liquid or solid phases to the gas phase. In plants, this involves increased rates of chemical synthesis and increased rates of cellular diffusion of VOCs at higher temperatures (Laothawornkitkul et al. 2009). Typically, semi-volatile organic compounds (sVOCs) are not emitted to the gas phase as easily as highly volatile and volatile compounds at lower temperatures (Pollmann et al. 2005; Schaub et al. 2010). Stickiness of these compounds, particularly at colder night temperatures, leads to adsorption/adherence on leaf surfaces of emitter and neighbouring plants and re-release of sVOCs back to the atmosphere when sunlight warms the foliage (Schaub et al. 2010; Himanen et al. 2010). This nocturnal adherence of unfamiliar sVOCs on the host plant may affect oviposition of herbivorous insects that lay eggs during colder evening dusk or early morning dawn or during total darkness such as many moth species (Uematsu and Yoshikawa 2002; Graf et al. 2015; Sambaraju et al. 2016). In theory, oviposition of insect species that prefer to lay eggs in daytime such as weevils (Greenberg et al. 2006) or plant bugs (Egonyu 2013) will be less affected, because unfamiliar sVOCs will have already evaporated from the plant surfaces. Limited evidence (Himanen et al. 2015) suggests that orientation of natural enemies on herbivore-damaged plants is not influenced by adhered compounds.

Plants may have different chemical defence strategies. In some plant species, several VOCs are produced in higher amounts only after attack by herbivores. This strategy is called induced defence, because there is limited investment of photosynthesised carbon into volatile compounds such as terpenes when plants are not under feeding stress (Kessler and Kalske 2018). Many plant species, such as aromatic herbs releasing a characteristic scent, constitutively produce significant amounts of secondary chemicals, including VOCs. These compounds are stored in specialised organs such as resin and latex canals or subcuticular and intercellular cavities in leaves (Pichersky and Raguso 2018) or in the plant epidermal GTs (Tissier et al. 2017). If such a plant is attacked by an herbivore, these compounds are released from broken storage structures and will often be repellent to the attacker. VOCs are also released from intact storage structures by diffusion in a temperature-dependent way, i.e. higher emissions are emitted from storage under warmer conditions (Copolovici and Niinemets 2015). The constitutively emitted VOCs act as attractive cues used by specialised herbivores to find the right host plant species. 
These chemicals are usually harmless to the digestion processes of specialised herbivores, while species specialised on other plant species may not be able to cope with these chemicals. In addition to constitutive VOC defence, plant chemical defence can be induced, which usually relates to indirect defence, i.e. the rapid increase in herbivore-induced volatiles, including de novo synthesis of sVOCs such as homoterpenes and SQTs (Arimura et al. 2008) that attract predators and parasitoids of herbivores. Thus, to understand the ecological impact of sVOCs, one needs to acknowledge their potential effects on insects of multiple trophic levels, and their differential responsiveness to biotic and abiotic variations (Yuan et al. 2009).

\section{How semi-volatiles differ from other volatile compounds?}

A strict definition of biogenic sVOCs and their difference from more volatile biogenic VOCs is not available. However, many anthropogenic semi-volatile organic compounds (sVOCs) are defined by the WHO as indoor pollutants that have a very high boiling point in the range of $240 / 260-360 / 400{ }^{\circ} \mathrm{C}$, which differs from very volatile organic compounds (boiling point $<100{ }^{\circ} \mathrm{C}$ ) and volatile organic compounds (boiling point in the range of $100-240{ }^{\circ} \mathrm{C}$ ) (Lucattini et al. 2018). Vapour pressure is an indication of a liquid's evaporation rate at a given temperature. Biogenic compounds with a vapour pressure below $0.005 \mathrm{kPa}$ at $25{ }^{\circ} \mathrm{C}$ are considered to be semi-volatile (Copolovici and Niinemets 2015). Physical properties of some of the common biogenic VOCs and semi-volatiles according to this classification are listed in Table 1. In aerosol science, the classification of VOCs is based on saturation vapour pressures, i.e. the pressure of a vapour, when it is in equilibrium with the liquid phase (Finlayson-Pitts 2017). Extremely low volatility organic compounds (ELVOC) and low volatility organic compounds (LVOC) are less volatile and more easily condense to form organic aerosols than the sVOCs and more volatile compound groups such as intermediate volatility organic compounds (IVOC) and volatile organic compounds (VOC) (Donahue et al. 2013).

Five carbon (C5) isoprene and one-carbon methanol are typical very volatile biogenic VOCs. Isoprene is the most abundant VOC emitted to the atmosphere by vegetation, while methanol is third after monoterpenes (MTs) (Messina et al. 2016). All terpenoids contain five-carbon isoprene units; they include an estimated 40.000 compounds in nature and are the most diverse and largest class of organic compounds in plants (Bohlmann and Keeling 2008). MTs (C10) are typical volatiles emitted by plants, and they could be emitted constitutively in a light dependent-way from chloroplasts or a temperature dependent-way from MT stores
(Ghirardo et al. 2010). MTs are emitted in higher amounts after herbivore damage, particularly from MT-storing plants (Heijari et al. 2011), but volatile (C6) green leaf volatiles (GLVs) are typically emitted from broken plant cells after mechanical or herbivore damage (Matsui et al. 2012). Methyl salicylate (MeSA) (C8) is a benzenoid and related to stress signalling in plants (Karl et al. 2008; Catola et al. 2018). MeSA production and emissions are often induced by feeding of sucking herbivores such as spider mites (Pinto et al. 2007) and aphids (Kasal-Slavik et al. 2017; Catola et al. 2018; Coppola et al. 2018), but less so by fungal pathogens (Kasal-Slavik et al. 2017). MeSA is classified as volatile according to boiling point temperature, but it has properties of sVOCs due to a very low vapour pressure (Table 1).

Sesquiterpenes (SQTs) are emitted from flowers (Schiestl 2010), leaves, stems (Wang et al. 2008; Schilmiller et al. 2010; Mofikoya et al. 2018a, b) or roots (Rasmann et al. 2005 ) and are major terpenoid sVOCs. The SQT blend emitted from herbivore-damaged or phytopathogen-damaged plants is often more diverse than that of intact plants (Pinto et al. 2007; Vuorinen et al. 2007; Arimura et al. 2008; Glas et al. 2012; Ponzio et al. 2013) and differs from damage by chewing or piercing-sucking arthropod herbivores (Leitner et al. 2005; Pinto et al. 2007; Ponzio et al. 2013). Herbivoreinduced production of SQTs and the SQT alcohol nerolidol is related to production of $\mathrm{C} 11$ and $\mathrm{C} 16$ homoterpenes $(E)$ 3,8-dimethyl-1,4,7-nonatriene (DMNT) and (E,E)-4,8,12trimethyltrideca-1,3,7,11-tetraene (TMTT), respectively (Arimura et al. 2008). Many herbivore-induced sVOCs such as SQTs and homoterpenes have shorter atmospheric lifetimes in polluted air (Pollmann et al. 2005; Pinto et al. 2007; Blande et al. 2010; Mofikoya et al. 2018a), and thus pollution reduces VOC signalling efficiency to natural enemies (Holopainen and Gershenzon 2010; Blande et al. 2014). Furthermore, air pollutants also degrade SQTs and MTs in floral scents and increase insect foraging times (Fuentes et al. 2016). Diterpenes (C20) are mostly non-volatile compounds and are important components of natural phytochemical mixtures along with MTs and SQTs. For example, diterpene resin acids are present in conifer oleoresin (Keeling and Bohlmann 2006), which is an important source of VOCs and sVOCs when exposed to air, while GTs on needle leaf laminas/surfaces contain bicyclic lambdane diterpenes (Xiao et al. 2017).

\section{Glandular trichomes as stores of biogenic sVOCs}

GTs on plant leaf or stem surfaces are estimated to be present in 30\% of vascular plants (Tissier et al. 2017). GTs are one of the most important synthesis and storage sites for leaf sVOCs (Wang et al. 2008; Glas et al. 2012). GTs 
Table 1 Physical properties of some typical biogenic volatiles listed according to their tendency to vaporise

\begin{tabular}{|c|c|c|c|c|c|}
\hline Compound & Chemical group & Chemical formula & $\begin{array}{l}\text { Vapour pressure }(\mathrm{kPa} \\
\left.\text { at } 25^{\circ} \mathrm{C}\right)\end{array}$ & $\begin{array}{l}\text { Melting point }\left({ }^{\circ} \mathrm{C} \text { at }\right. \\
760 \mathrm{mmHg})\end{array}$ & $\begin{array}{l}\text { Boiling point }\left({ }^{\circ} \mathrm{C}\right. \\
\text { at } 760 \mathrm{mmHg})\end{array}$ \\
\hline Very volatile & & & & & $0-100$ \\
\hline Methanol & Alcohol & $\mathrm{CH}_{4} \mathrm{O}$ & 13.20 & -97.6 & 64.7 \\
\hline Acetaldehyde & Aldehyde & $\mathrm{C}_{2} \mathrm{H}_{4} \mathrm{O}$ & 98.66 & -123.4 & 20.2 \\
\hline Isoprene & Isoprenoid & $\mathrm{C}_{5} \mathrm{H}_{8}$ & 53.20 & -146.0 & 34.1 \\
\hline Volatile & & & & & $100-240$ \\
\hline (Z)-3-hexenal & Aldehyde (GLV) & $\mathrm{C}_{6} \mathrm{H}_{10} \mathrm{O}$ & 1.49 & -78.9 & 116.5 \\
\hline (Z)-3-hexenol & Alcohol (GLV) & $\mathrm{C}_{6} \mathrm{H}_{12} \mathrm{O}$ & 0.14 & -61.0 & 168.9 \\
\hline (Z)-3-hexenyl acetate & Acetate (GLV) & $\mathrm{C}_{8} \mathrm{H}_{14} \mathrm{O}_{2}$ & 0.16 & -26.2 & 169.0 \\
\hline Benzaldehyde & Aldehyde & $\mathrm{C}_{7} \mathrm{H}_{6} \mathrm{O}$ & 0.17 & -26.0 & 178.0 \\
\hline$\alpha$-Pinene & MT & $\mathrm{C}_{10} \mathrm{H}_{16}$ & 0.63 & -62.8 & 156.9 \\
\hline Limonene & MT & $\mathrm{C}_{10} \mathrm{H}_{16}$ & 0.26 & -96.0 & 175.0 \\
\hline$\beta$-Myrcene & MT & $\mathrm{C}_{10} \mathrm{H}_{16}$ & 0.28 & -110.5 & 167.0 \\
\hline$\beta$-Ocimene & MT & $\mathrm{C}_{10} \mathrm{H}_{16}$ & 0.21 & -110.0 & 174.5 \\
\hline Linalool & MT alcohol & $\mathrm{C}_{10} \mathrm{H}_{18} \mathrm{O}$ & 0.12 & -28.3 & 198.7 \\
\hline Menthone & Cyclic MT alcohol & $\mathrm{C}_{10} \mathrm{H}_{18} \mathrm{O}$ & 0.03 & -6.0 & 210.0 \\
\hline Carvacrol & MT phenol & $\mathrm{C}_{10} \mathrm{H}_{14} \mathrm{O}$ & $0.00399^{\mathrm{a}}$ & 2.5 & 237.7 \\
\hline Citral & MT aldehyde & $\mathrm{C}_{10} \mathrm{H}_{16} \mathrm{O}$ & 0.01 & -10.0 & 229.0 \\
\hline DMNT & Homoterpene & $\mathrm{C}_{11} \mathrm{H}_{18}$ & $0.08^{\mathrm{b}}$ & -99.0 & 182.5 \\
\hline Methyl salicylate ${ }^{\mathrm{c}}$ & Methyl ester & $\mathrm{C}_{8} \mathrm{H}_{8} \mathrm{O}_{3}$ & $0.00457^{\mathrm{a}}$ & -8.6 & 222.2 \\
\hline (Z)-sabinyl acetate & MT acetate & $\mathrm{C}_{12} \mathrm{H}_{18} \mathrm{O}_{2}$ & 0.00879 & n.a. & 230.0 \\
\hline Semi-volatile & & & $<0.005$ & & $>240$ \\
\hline Geranyl acetate & Acetate & $\mathrm{C}_{12} \mathrm{H}_{20} \mathrm{O}_{2}$ & 0.00347 & n.a. & 242.0 \\
\hline Geranyl acetone & MT ketone & $\mathrm{C}_{13} \mathrm{H}_{22} \mathrm{O}$ & 0.00213 & n.a. & 247.0 \\
\hline Eugenol & Phenylpropene & $\mathrm{C}_{10} \mathrm{H}_{12} \mathrm{O}_{2}$ & 0.00133 & 100.3 & 255.0 \\
\hline Indole & Heterocyclics & $\mathrm{C}_{8} \mathrm{H}_{7} \mathrm{~N}$ & 0.00163 & 51.5 & 253.5 \\
\hline$\beta$-Elemene & SQT & $\mathrm{C}_{15} \mathrm{H}_{24}$ & 0.00368 & n.a. & 252.0 \\
\hline$\beta$-Caryophyllene & SQT & $\mathrm{C}_{15} \mathrm{H}_{24}$ & 0.00173 & 50.6 & 263.0 \\
\hline$\alpha$-Selinene & SQT & $\mathrm{C}_{15} \mathrm{H}_{24}$ & 0.00160 & n.a. & 270.0 \\
\hline$\alpha$-Farnesene & SQT & $\mathrm{C}_{15} \mathrm{H}_{24}$ & 0.00133 & -73.2 & 278.3 \\
\hline$\beta$-Farnesene & SQT & $\mathrm{C}_{15} \mathrm{H}_{24}$ & 0.00133 & $<-70.0$ & 272.5 \\
\hline Ledene & SQT & $\mathrm{C}_{15} \mathrm{H}_{24}$ & n.a. & -73.7 & 269.0 \\
\hline Aromadendrene & SQT & $\mathrm{C}_{15} \mathrm{H}_{24}$ & 0.00306 & 57.3 & 283.6 \\
\hline Nerolidol & SQT alcohol & $\mathrm{C}_{15} \mathrm{H}_{26} \mathrm{O}$ & 0.00013 & -75.0 & 275.7 \\
\hline Cedrol & SQT alcohol & $\mathrm{C}_{15} \mathrm{H}_{26} \mathrm{O}$ & 0.00013 & 86.5 & 277.2 \\
\hline Ledol & SQT alcohol & $\mathrm{C}_{15} \mathrm{H}_{26} \mathrm{O}$ & 0.00002 & 104.0 & 293.9 \\
\hline Palustrol & SQT alcohol & $\mathrm{C}_{15} \mathrm{H}_{26} \mathrm{O}$ & 0.00002 & 76.1 & 293.5 \\
\hline$\beta$-Eudesmol & SQT alcohol & $\mathrm{C}_{15} \mathrm{H}_{26} \mathrm{O}$ & 0.00001 & 72.0 & 301.5 \\
\hline TMTT & Homoterpene & $\mathrm{C}_{16} \mathrm{H}_{26}$ & $<0.001$ & -62.0 & 301.1 \\
\hline Methyl jasmonate ${ }^{c}$ & Methyl ester & $\mathrm{C}_{13} \mathrm{H}_{20} \mathrm{O}_{3}$ & 0.00013 & $<25.0$ & 302.5 \\
\hline Germacrene D & SQT & $\mathrm{C}_{15} \mathrm{H}_{24}$ & 0.00093 & -8.5 & 308.0 \\
\hline Globulol & SQT alcohol & $\mathrm{C}_{15} \mathrm{H}_{26} \mathrm{O}$ & 0.00002 & 124.1 & 372.2 \\
\hline
\end{tabular}

Chemical compound information was collected from the ChemSpider (http://www.chemspider.com), Chemeo (https://www.chemeo.com/) and The Good Scent Company (http://www.thegoodscentscompany.com) databases. Classification follows the WHO classification for volatile organic pollutants according to their boiling points (Lucatti et al. 2018). Vapour pressure is an indication of a liquid's evaporation rate at a given temperature. Biogenic compounds with a vapour pressure below $0.005 \mathrm{kPa}$ at $25{ }^{\circ} \mathrm{C}$ are considered semi-volatiles (Copolovici and Niinemets 2015)

$G L V$ green leaf volatiles, $M T$ monoterpene, $S Q T$ sesquiterpene, $D M N T(E)$-3,8-dimethyl-1,4,7-nonatriene, $T M T T(E, E)$-4,8,12-trimethyltrideca1,3,7,11-tetraene, $n . a$. not available

${ }^{a}$ According to their low vapour pressure value these compounds can be classified as semi-volatiles

bhttps://www.guidechem.com/

${ }^{\mathrm{c}}$ Compound has plant hormone properties 
on leaf and stem surfaces (Fig. 2) are involved in direct defence, with effects on the orientation and locomotion of herbivorous insects before they start feeding (Voigt et al. 2007; Simmons and Gurr 2005; LoPresti 2016; Tissier et al. 2017). There are several types of GTs, and each plant species may have one or more types (Simmons and Gurr 2005; McDowell et al. 2011), but GTs may differ substantially in their chemical content, even between related plant species. The essential oil composition of GT glands is predominantly composed of mixtures of MTs and SQTs, particularly in species of the family Lamiaceae (Jin et al. 2014; Xiao et al. 2017; Yu et al. 2018). SQTs are also found in GTs of the plant families Asteraceae (Bezerra et al. 2018), Solanaceae (McDowell et al. 2011) and Geraniaceae (Kremer et al. 2013). Oxidised SQTs can be found in GTs of the families Asteraceae (Piazza et al. 2018), Rosaceae (Hashidoko et al. 1994) and Ericaceae (Mofikoya et al. 2018a). GTs in some species of the Solanaceae family may have, in addition to MTs and SQTs, a highly diverse set of non-volatile metabolites including flavonoids and other phenylpropanoids, alkaloids, fatty acids and acyl sugars (McDowell et al. 2011; Glas et al. 2012). Other less volatile and viscous materials in plant GTs include diterpenoids (Xiao et al. 2017) and triterpenoids (Frenzke et al. 2016). Genomic analysis of Solanum spp. (McDowell et al. 2011) revealed that in addition to genes related to secondary metabolite production, some GT types express genes associated with photosynthesis and carbon fixation and some may have functions related to the synthesis of protease inhibitors. In a Mentha sp., the lack of photosynthetic transcripts in the GT transcriptome suggests that in this species energy production in GTs is dependent on an exogenous supply of sucrose from underlying leaf tissues (Jin et al. 2014).

High concentrations of MTs and SQTs in GTs are toxic to herbivorous insects and reduce their activity, feeding, oviposition and substantially increase their mortality (Simmons and Gurr 2005). Non-glandular trichomes, together with GTs, may also act in mechanical defence against herbivores (Simmons and Gurr 2005). MTs and SQTs are reactive with ozone $\left(\mathrm{O}_{3}\right)$, and when stored in GTs on leaf surfaces GTs also give protection against phytotoxic $\mathrm{O}_{3}$, but non-glandular trichomes without reactive compounds do not provide $\mathrm{O}_{3}$ protection ( $\mathrm{Li}$ et al. 2018). A high content of unsaturated fatty acids in GTs of some Solanum spp. act as repellents of herbivorous spider mites (Murungi et al. 2016). Stalked GTs on Solanaceous plants can contain highly viscous and hydrophobic acyl sugars (Voigt et al. 2007; McDowell et al. 2011; Weinhold and Baldwin 2011). The sticky content of broken GTs is a direct plant defence against herbivory that catches insects (Krimmel and Pearse 2013). Removal of GT exudates from surfaces may lead to an improved rate of parasitism on herbivorous insects by specific small parasitoids (Simmons and Gurr 2005). However, the entrapped insect carrion (Fig. 2) on glandular leaves has been found to constitute an alternative and attractive food source for generalist predators, thus improving indirect defence of plants by increasing the number of predators on plant foliage (Voigt et al. 2007; Krimmel and Pearse 2013; LoPresti et al. 2018). This represents an additional indirect defence-strategy to the specialised herbivore-induced plant VOCs that lead to attraction of specialised parasitoids and predators of the herbivores.

One of the evolutionary reasons for the location of GTs on plant surfaces is the phytotoxicity of oily MTs in high concentrations (Tissier et al. 2017; Synowiec et al. 2017). To avoid phytotoxicity for the terpene secretory tissues, GTs have special compartments (Tissier et al. 2017; Mofikoya et al. 2018b) filled with essential oils, i.e. MTs mixed with SQTs and other compounds mentioned above. However, there are no studies of how high concentrations of MTs in GTs affect the fluidity and possible volatility of other less volatile compounds in GTs. For example, in resin canals of conifers high oleoresin MT concentrations maintain fluidity of solid resin acids (da Silva Rodrigues-Corrêa et al. 2013). High temperature dependence of volatility of VOCs may lead mixtures of MTs and SQTs to escape directly to the atmosphere by passive diffusion through the GT cuticle during warmer temperatures (Niinemets et al. 2014; Tissier et al. 2017). Released SQTs (Mofikoya et al. 2018b), SQT alcohols (Himanen et al. 2010; Mofikoya et al. 2018b) and monoterpenes (Mofikoya et al. 2017, 2018b) have been observed to deposit on neighbouring plant foliage in field conditions. Re-emission of these deposited SVOCs from neighbour foliage has been shown to be highest in the morning (Himanen et al. 2010).

\section{Uptake of VOCs and sVOCs from the atmosphere by plants}

The behaviour of biogenic sVOCs in ecosystems and their impact on ecosystem function is still poorly understood compared to that of sVOC indoor pollutants (Lucattini et al. 2018) and sVOCs in different layers of the atmosphere (Donahue et al. 2013). A microcosm experiment indicated that soil is the major sink of isoprene and the MT $\alpha$-pinene compared to grasses growing in the microcosm (Spielmann et al. 2017), although vegetation significantly reduced soil sink, when compared to bare soil. Monitoring of anthropogenic sVOCs in forest ecosystems has indicated that forest canopies are important for SVOC deposition and accumulation (Horstmann and McLachlan 1998). Results also suggested that lipophilic sVOCs are taken up from the atmosphere by the leaf/needle cuticle and not just via the stomata (Horstmann and McLachlan 1998). It should be noted that both biogenic and anthropogenic VOCs and sVOCs may 
become involved in atmospheric aerosol reactions, which may change their volatility to lower or even to ELVOCs or solid organic particles (Donahue et al. 2013; Holopainen et al. 2017) before deposition on plants. However, these reaction products are outside the scope of our review.

When comparing the proportion of biogenic sVOCs in the emissions from plant leaves and in the flux above the canopy, e.g. in orange orchards (Ciccioli et al. 1999), a considerable loss in atmospheric concentrations of SQTs can be observed. This can be related to the atmospheric reactivity of biogenic VOCs and sVOCs (Jardine et al. 2011; Holopainen and Blande 2013; Liebmann et al. 2018; Mofikoya et al. 2018a) or their loss to leaf surface adsorption during the night hours or uptake through stomata during active $\mathrm{CO}_{2}$ uptake (Niinemets et al. 2014). Examples of specific VOCs and sVOCs emitted from one plant and deposited on the foliage of other plants, from the same or other species, are still limited. Deposition flux of MTs and SQTs typical of nearby conifer forest trees was detected in mountain grassland (Bamberger et al. 2011). Substantial recovery of MTs, SQTs and SQT alcohols typical of the understory shrub Rhododendron tomentosum Harmaja (Ericaceae) (Jesionek et al. 2017) was made from mountain birch foliage in the subarctic (Mofikoya et al. 2018b). Earlier, Himanen et al. (2010) reported recovery of $R$. tomentosum SQT alcohols from the foliage of Betula pendula Roth and B. pubescens Ehrh. (Betulaceae) particularly in the morning, if saplings were grown close to $R$. tomentosum shrubs. These examples show that plants can adsorb VOCs and sVOCs from other plant species when they grow in the same environment. Under experimental conditions, high atmospheric concentrations of the MT limonene were taken up by individuals of several plant species and released back to the atmosphere in limonene-free air (Noe et al. 2008). Variation in uptake rate of this hydrophobic MT was best explained by leaf lipid content of the exposed plants.

An evaluation of the commonality of uptake of volatiles emitted by neighbouring plants is not available, but results of Noe et al. (2008) suggest that there is significant uptake of hydrophobic MTs when the density of monoterpeneemitting plants and ambient air concentrations of MTs are high. Stomatal uptake of highly volatile VOCs such as acetaldehyde by plants is known (Niinemets et al. 2014 and references therein). Several sVOCs and many less volatile hydrophobic compounds have been described on leaf surface epicuticular waxes of crop plants (e.g. Szafranek et al. 2006, 2008). However, the understanding of deposition of VOCs and sVOCs on target plant leaves from their neighbours is often masked by the emission of similar compounds from both plant species. For example, the MT $\beta$-myrcene and the SQT $\beta$-farnesene are both emitted by Betula species and $R$. tomentosum shrubs (Himanen et al. 2010), so their origin on Betula leaves could be from either sources, the emitter or the neighbour. Highly species specific sVOCs of an emitter plant are the best indicators of VOC deposition on neighbouring plants in nature (Mofikoya et al. 2018b).

\section{Do sVOCs deposited on leaf surfaces affect herbivorous insects?}

Kessler and Kalske (2018) suggested that adsorbing and reemitting VOCs from neighbouring plants could be potentially a common, but rarely studied, mechanism of associational resistance in nature. If a plant is naturally covered by sVOCs of another plant species and releasing a strange scent, it represents a case of environmentally acquired chemical camouflage (Kessler and Kalske 2018). So far, there are only a few examples of this process from laboratory conditions (Himanen et al. 2010, 2015), from experimental fields (Himanen et al. 2010) and from forest environments (Mofikoya et al. 2018b) and none directly from agroecosystems documenting the release of adhered exogenous sVOCs of neighbouring plants. Under laboratory conditions, there is also evidence that uninfected plants downwind can uptake herbivore-induced volatiles from conspecific infested plants (Choh et al. 2004). In addition to potential effects of companion plant sVOCs adsorbed on crop plant surface (Fig. 3), stomatal uptake of external VOCs such as MTs (Copolovici et al. 2005) and sVOCs such as indole (Erb 2018) may have positive effects on abiotic and biotic stress tolerance of crop plant.
Fig. 3 A schematic illustration of potential VOCs and sVOCs functions in companion/ secondary plant-crop plant interactions related to surface adsorption and stomatal uptake of companion plant emissions by crop plant and potential consequences for herbivore tolerance of crop

\section{Companion plant as VOC and sVOC emitter}

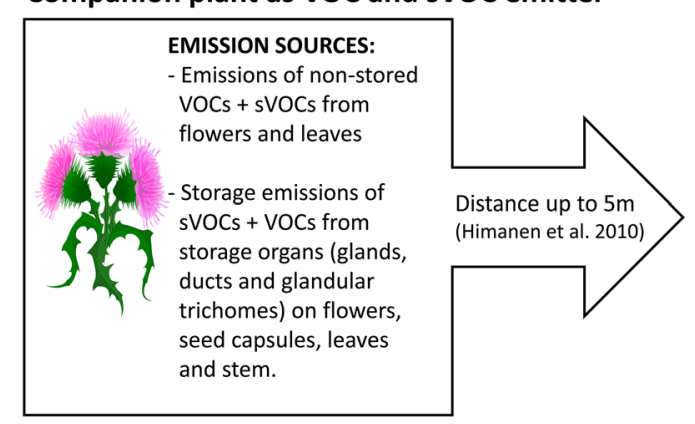

Crop plant as VOC and sVOC receiver

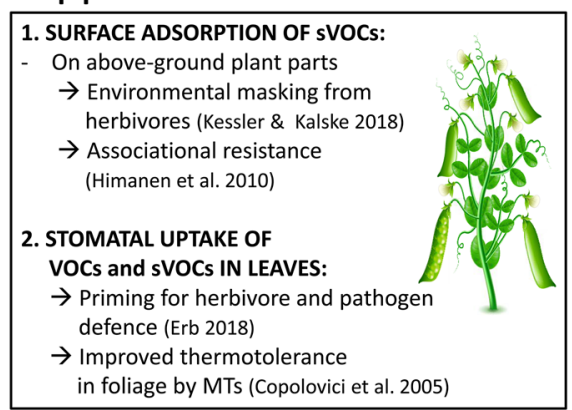


Plant extracts or distilled essential oils, containing MTs or MT and SQT mixtures, have been traditionally used to control plant-damaging insects (Ibrahim et al. 2001; Kumar et al. 2011; Gahukar 2012; Yarou et al. 2017). In direct contact, some plant extracts and distilled essential oils have been found to be nearly equally as effective as synthetic insecticides against certain plant-feeding and bloodfeeding arthropods (Jaenson et al. 2005; Yarou et al. 2017). These compounds can also accumulate on plant surfaces and through their smell provide repellency and protection against attacking insects (Ibrahim et al. 2001, 2005; Yarou et al. 2017). Extracts and essential oils can be sprayed on plants or released from various dispensers (Ibrahim et al. 2005; Mofikoya et al. 2017; Salamanca et al. 2018). Plant extracts may affect orientation behaviour or host acceptance by the herbivorous insects, but also attract some parasitoids of the pest insect (Ibrahim et al. 2005; Egigu et al. 2010). However, in high concentrations phytotoxic MTs sprayed on plant surfaces may lead to substantial reduction of photosynthesis and visible damage in crop plant foliage (Ibrahim et al. 2004). Direct spraying of plant extracts may also leave residues of various metabolites of the extracted plant on the edible crop plant and cause a potential health risk of humans, if containing toxic compounds in high concentrations (Gahukar 2012).

Promotion of natural adsorption of VOC and sVOC compounds to crop plants from an emitting secondary plant could be an alternative option for arthropod pest control to direct crop plant treatment with plant extracts or essential oils. For more than three decades, it has been known that plants in the neighbourhood of herbivore-damaged plants become better defended and more resistant than healthy plants that are situated further (Baldwin and Schultz 1983). It took nearly two more decades to demonstrate that induced-VOCs emitted by damaged leaves transmit the signal to activate defence in healthy parts of the same plant, but these VOC signals are also eavesdropped upon by neighbouring plants leading to defence activation (Arimura et al. 2000; Karban and Maron 2002; Kost and Heil 2006; Frost et al. 2007; Heil and Silva Bueno 2007). The responsive plants can be conspecific or heterospecific healthy plants (Heil and Karban 2010). Many of the herbivore-induced compound are terpenes. In laboratory tests, emissions of the MT $\beta$-ocimene, homoterpene DMNT and sVOC homoterpene TMTT activated expression of genes related to phenolic and terpenoid pathways in receiver plants (Arimura et al. 2000). In Populus L. species (Salicaceae), herbivory, mechanical damage and exogenous methyl jasmonate application-induced germacrene D synthase gene expression and emission of the SQT (Arimura et al. 2004).

Many aromatic plant species constitutively emit a relatively large proportion of SQTs. E.g. some Mentha spp. may have a SQT proportion exceeding $16 \%$ (Yu et al. 2018) and
50\% (Omaya-Okubo 2012) in extracted essential oil and volatile emissions, respectively. In some aromatic herbs, SQT alcohols may represent more than $40 \%$ of total root essential oil (Bottini et al. 1987). In the SQT-rich shrub $R$. tomentosum, the emission of SQTs and SQT alcohols varies from $31 \%$ (Himanen et al. 2010) to more than $60 \%$ of total VOC emissions (Himanen et al. 2015). Emissions of SQTs are normally diurnal and peak in daytime (Schaub et al. 2010), when the temperature is high enough for diffusion from storage and there is enough light for photosynthesis and thus carbon availability for biosynthesis (Arimura et al. 2004). Potential high emission rates of sVOCs close to emitter plants supports the idea that constitutive emissions of VOCs, and sVOCs could cause other plants to elicit or prime defences (Sukegawa et al. 2018). Also, the repellent role of the sVOCs may exist on the foliage of other plants, when SVOCs are deposited there (Himanen et al. 2010, 2015).

Depending on climatic conditions in the region, the diurnal adsorption-desorption cycle may be possible with sVOCs (Himanen et al. 2010). When the foliage of emitter plants becomes warmer during daytime hours, more sVOCs are emitted (Schaub et al. 2010). Highest emission rates of sVOCs from neighbouring receiver plant surfaces can also be detected in the cooler mornings when adsorbed molecules become more volatile on warming leaves (Himanen et al. 2010). The proportion of oxidised sVOCs such as SQT alcohols could be higher in re-emitted VOCs, because they are less reactive with atmospheric oxidants such as ozone (Mofikoya et al. 2018a). In colder climates, with cooler night temperatures during growing seasons, more distinctive adsorption of monoterpenes from neighbouring plants can be detected (Mofikoya et al. 2018b). However, when a sVOC-emitting plant and a crop plant were grown together for $24 \mathrm{~h}$ at constant $+6{ }^{\circ} \mathrm{C}$ or $+22^{\circ} \mathrm{C}$ temperatures in controlled laboratory conditions, adsorption of sVOCs were only detected at $+22{ }^{\circ} \mathrm{C}$ (Himanen et al. 2015). This suggests that sVOC adsorption on neighbouring plants in nature should also be studied in warmer climatic conditions.

Constitutively emitted volatiles of Mentha species grown together with Glycine max L. (Merr.) (Fabaceae) or Brassica rapa $\mathrm{L}$. (Brassicaceae) activated defence genes such as trypsin inhibitor genes and pathogenesis-related genes in receiver crop plans (Sukegawa et al. 2018). These plants received significantly lower levels of herbivory by natural herbivores in the field and in a greenhouse when compared to control plants that were not first exposed to Mentha plant volatiles. Sukegawa et al. (2018) suggested that the activation of defence genes might be related to increased depolarisation of the membrane potential by high concentrations of typical Mentha VOCs such as menthofuran, pulegone, neomenthol, menthol and menthone. Binding of Mentha VOCs to the cell membranes of receiver plants possibly altered ion permeability of the plasma membrane 
and triggered an oxidative burst. It has also been observed that cabbage plants (Brassica oleracea convar. capitata L., Brassicaceae) exposed to herbivore-damaged conspecifics in the field are primed for stronger emission of VOCs (GironCalva et al. 2017) and are less susceptible to oviposition by the diamondback moth (Plutella xylostella L.; Lepidoptera, Plutellidae) (Giron-Calva et al. 2016). Laboratory studies confirmed this observation but also showed that cabbage plants exposed to herbivore-damaged broccoli were more susceptible to oviposition by $P$. xylostella (Giron-Calva et al. 2016). The mechanism underpinning the latter observation is likely to be the adsorption of sesquiterpenes, as observed in mechanistic laboratory studies by Li and Blande (2015). Another similar adsorption mechanism related to VOC and sVOC effects on crop plant herbivores was described by Himanen et al. (2015). Parts of B. oleracea plants were first grown for $48 \mathrm{~h}$ close to $R$. tomentosum where they adsorbed the MT myrcene and SQT alcohols ledol and palustrol. In laboratory experiments, these plants had lower oviposition pressure by $P$. xylostella than unexposed control plants. The reason for the reduced herbivore pressure was suggested to be a masking of the crop plant scent by adsorption of an unfamiliar scent of the secondary plant (Himanen et al. 2015; Kessler and Kalske 2018). In this study, the possibility of activation of crop plant defence genes by the constitutively emitted VOCs and sVOCs was not analysed.

An advantage of improving crop plant pest resistance by constitutively emitted VOCs and sVOCs of the emitter plant is that the active compounds produced by the secondary plant will continuously adhere to plant surfaces when the crop plant is growing, and not only on the days of spraying treatment. Another advantage is that no significant amounts of residue of emitter plants accumulate on crop plants, because they are normally re-emitted in warmer daytime temperatures. A disadvantage is the strong dependence of adsorption on weather conditions including wind direction, temperature and precipitation. Furthermore, the ontogenetically varying production of VOC and SVOC production during the growing season (Mofikoya et al. 2018b) might not match with the life cycle (e.g. oviposition and larval feeding periods of the herbivore) leading to reduced pest management effects.

\section{SVOC-producing secondary plants in sustainable crop production systems}

VOC and sVOC emissions and their induction are plant traits that are controlled by multiple genes. Domestication and plant breeding have reduced induction and emission capacities in many crop plants (Glas et al. 2012; Stenberg et al. 2015; Lee at al. 2019). Crossing back these traits into crop plants might take significant time and may impair other crop plant traits such as productivity and quality of current cultivars (Andersen et al. 2015; Palmgren et al. 2015). An alternative is to use aromatic wild plants or cultivars of crop plants as alternative producers (secondary plant) of volatile repellents from crop plants (push) or attractants to secondary plants (pull) to manipulate behaviour of pest species on crop plants (Song et al. 2014). When considering the effects of sVOC-emitting plants on crop plants, we should keep in mind that $\mathrm{SVOC}$ emitters also emit other, more volatile VOCs such as MTs (Himanen et al. 2010; Mofikoya et al. 2018b). Thus, the potential effects on crop plants and their arthropod communities will be based on the interactive effects of these compounds, and it is often not possible to separate the ultimate effects of VOCs or sVOCs. It is the same with the use of plant extracts or essential oils released from dispensers, where many of the sVOCs are less common than monoterpenes (Demasi et al. 2018). Parolin et al. (2012) defined secondary plants used in cropping systems as all different types of plants or crops grown together with a primary crop for pest management purposes. Such plants can be divided into several categories including companion, repellent, barrier, indicator, trap, insectary and banker plants. Potential role of sVOCs of secondary plants in these categories is summarised in Table 2.

Intercropping (Stenberg et al. 2015) or service cropping (Garcia et al. 2018), growing two or more plant species together in space and time for part or the whole of their growth cycle, has been re-discovered and becoming a central means for ecological intensification, as it potentiates various types of diversification benefits (Brooker et al. 2015). Intercrop selection is often made based on yielding (targeting over-yielding, biological nitrogen fixation to supply additional nitrogen, or desired crop quality in feed mixtures), while improved pest control and associated functional biodiversity are also advantages of intercropping (Mutisya et al. 2016). Intercropping may be targeted at reducing reliance on synthetic pesticides by replacing them with natural pest buffering strategies. An altered physical or chemical environment can modify the arthropod community above- and below-ground when several, typically crop species, co-exist. Intercropping potentiates the disturbance of insect pest host location (through visual or olfactory camouflage), of spread or reproduction in the canopy or root environment or can have an impact via support of top-down control by natural enemies (reviewed by, e.g. Poveda et al. 2008 and; Ratnadass et al. 2012). Although volatile communication in soil ecosystems is still rather poorly known (Delory et al. 2016), the role of sVOCs such as SQTs in attracting entomopathogenic nematodes of root herbivores by volatile communication in moist soil airspace is well documented (Rasmann et al. 2005; Hiltpold and Turlings 2012). One important thing related to using volatile-based strategies in intercropping 
Table 2 Potential functions of sVOC-rich secondary/companion plants in sustainable crop production systems and push-pull pest control strategies

\begin{tabular}{|c|c|c|}
\hline Secondary plant role & Potential functions of sVOC of secondary plant & Outcome on crop \\
\hline Repellent plant & $\begin{array}{l}\text { 1. Repel flying insects (push) } \\
\text { 2. Acquired chemical camouflage on crop plant (push) } \\
\text { 3. Potential elicitor }\end{array}$ & $\begin{array}{l}\text { Reduced pest pressure (less pest arrival and arrestment to } \\
\text { the field) } \\
\text { Lower acceptance by pests } \\
\text { Induced defences on crop plant and increased attraction of } \\
\text { natural enemies (potentially increased parasitisation and } \\
\text { predation rates) }\end{array}$ \\
\hline Companion plant & $\begin{array}{l}\text { 1. Root exudates reduce soil pests } \\
\text { 2. Attract pest from crop (pull) } \\
\text { 3. Attract pollinators and natural enemies }\end{array}$ & $\begin{array}{l}\text { Less damage in root system } \\
\text { Less damage in foliage } \\
\text { Potentially improved pollination, increased parasitisation } \\
\text { and predation rates }\end{array}$ \\
\hline Trap plant & $\begin{array}{l}\text { Attract and trap crop herbivores (pull) } \\
\text { Induced emissions attract natural enemies }\end{array}$ & $\begin{array}{l}\text { Reduced pest pressure } \\
\text { Higher abundance and/or diversity of predators and parasi- } \\
\text { toids in the field }\end{array}$ \\
\hline Barrier plant & Attract and stop arrival of herbivorous insects (pull) & Reduced insect damage \\
\hline Indicator (sentinel) plant & Attract key pest more efficiently than crop plant (pull) & Plant monitoring-improved timing of pest control measures \\
\hline Insectary plant & $\begin{array}{l}\text { Flower emissions attract adult predators and parasitoids } \\
\text { to feed on nectar and pollen and attack crop pests }\end{array}$ & $\begin{array}{l}\text { Improved natural pest control by parasitoids and predators } \\
\text { Higher arthropod abundance and/or diversity }\end{array}$ \\
\hline Banker plant & $\begin{array}{l}\text { Attract adult predators and parasitoids to reproduce on } \\
\text { the plant } \\
\text { Stimulate host herbivore nymphs and larvae to feed on } \\
\text { banker plant }\end{array}$ & $\begin{array}{l}\text { Sustained population of natural enemies to control pests in } \\
\text { greenhouse conditions }\end{array}$ \\
\hline
\end{tabular}

Classification of secondary plant types according to Parolin et al. (2012)

is understanding the effective distance, specificity of the cues to target and non-target insects, and potential linkages to other ecological mechanisms that can also contribute to the crop-herbivore-natural enemy dynamics.

When pest control is the main goal of using intercropping, selection of crops is based on desired attraction or repulsion properties of the yielding or associate crops to key pests and/or their natural enemies. The strength of the volatile-based attraction needs to be high enough to deliver the desired efficacy; thus, theoretically, specialised pest species relying more on olfactory cues are likely to be more affected than various generalist species. The use of "trap" plants to attract pest insects away from the crop plant was already presented in 1860 by an English entomologist John Curtis (Curtis 1860; Lamy et al. 2018), but practical applications were not developed earlier than the 1960s, when Stern et al. (1969) used an alfalfa intercrop to effectively reduce Lygus spp. (Heteroptera: Miridae) bug damage on cotton. The most well-known examples of volatile-based intercropping systems are the various push-pull systems (Eigenbrode et al. 2016). Functional, i.e. providing yield securing, examples include the push-pull system designed to defend maize and sorghum crops from the maize stemborer (Chilo partellus Swinhoe; Lepidoptera, Crambidae) and the parasitic weed Striga hermonthica (Delile) Benth. (Orobanchaceae). In the conventional system, an intercrop and a trap crop are used as companion crops. The intercrop is a Desmodium Desv. species (Fabaceae), which has multiple functions in the system, it is repellent to moths, inhibits successful parasitism by $S$. hermonthica, and fixes nitrogen to improve soil quality. The trap crop is Napier grass (Pennisetum purpureum Schumach.; Poaceae), which is attractive to moths but unsuitable for their development. Both companion crops are harvested as fodder for livestock, thus optimising the overall yield obtained from the system (Cook et al. 2007; Khan et al. 2010). In broccoli-Chinese cabbage intercropping (Brassica oleracea var. italica Plenck-B. rapa; Brassicaceae), a push-pull system was successfully enhanced against Plutella xylostella by additional dispensers releasing dimethyl disulfide as a push component in a broccoli crop and Z-3-hexenyl-acetate as a pull component in Chinese cabbage strips (Lamy et al. 2018).

Information on preferences of specialist herbivores towards different crop species or cultivars, e.g. earlier flowering, preferred flower colour or scent have been used as the basis of various trap cropping strategies (reviewed by, e.g. Hokkanen 1991; Parolin et al. 2012; Sarkar et al. 2018). Dead-end trap crops have the benefit of fast and cost-effective reduction of pest populations (e.g. Shelton and Nault 2004). Trap crop spatiotemporal placement can also modify the efficacy of the system: attraction and arrestment of the pest on the trap crop, and this can be variable on herbivores relying on olfactory and visual cues versus post-alighting cues (Potting et al. 2005). The trap crops seldom include specific sVOC-emitters, but rather resemble the main crop while having higher attractiveness to the attacker. One of the 
potential repellence strategies that relies on aromatic volatiles is based on the repulsive effects of lavender (Lavandula angustifolia Mill.; Lamiaceae) odour on immigrating pollen beetles (Brassicogethes aeneus Fab.; Coleoptera, Nitidulidae) (Mauchline et al. 2013). The study used MTand SQT-rich lavender essential oil (Demasi et al. 2018) to mask Brassica odour. Using SQT and SQT alcohol-rich plant extracts sprayed on crop plants may act as repellents to the herbivore, but may at the same time even improve the attraction of specialist parasitoids (Egigu et al. 2010). These opposite responses of a herbivore and its enemy maywhere a MT is known to be repellent to a pest and SQTs are known to attract the parasitoid (Ibrahim et al. 2005) allow for application whereby the compounds are released in combination from dispensers in the main crop. Selecting natural enemy-favouring secondary plants for intercropping can combine enhanced attractiveness by VOCs with direct support by floral nectar and pollen. The strategy of combining a herbivore-induced attractant methyl salicylate and a floral nectar reward (buckwheat Fagopyrum esculentum Moench; Polygonaceae) has been trialled for supporting on conservation biological control (Orre-Gordon et al. 2013).

In terms of field plot responses, it is noteworthy that the spatial configuration of intercropping can also contribute to the efficacy against pests and impacts on natural enemies. For example, in wheat intercropping systems, strip cropping has been reported to more often reduce pest populations and favour natural enemies than relay or mixed intercropping (Lopes et al. 2016). How the type of intercropping impacts on potential sVOC-based interactions needs further study. The risks to efficacy when using volatile-based pest control based on chemicals originating from plant sources relate to their high responsiveness to abiotic and biotic variation, potentially restricted efficacy (with some herbivores not relying on volatile cues), and ability of herbivores to adapt to the altered volatile environment and break the resistance if the trap crop is not a developmental dead-end for the pest and thus pesticidal. One major advantage in using intercropping is that both crops can usually be commercially used to add profitability to the use of agricultural fields. Adaptations of intercropping in organic farming can include trap crops, such as using early cultivars to attract pest insects to reproduce there (Cotes et al. 2018). In the attract-and kill strategy (Gregg et al. 2018), the pest insect species can be controlled with permitted natural insecticides applied to the trap crop to reduce chemical control on the main cultivar. Trap crops in this type of "push and pull" strategy have been used particularly efficiently in developing countries and sVOCs such as SQTs of trap crop species have important roles in pest attraction from the main crop (Pickett and Khan 2016).

VOC-emitting secondary plants, e.g. aromatic plants such as mint (Sukegawa et al. 2018), might not be suitable for growing alongside crops currently grown in large monocultures such as cereals and leguminous crops. Development of the system would at least need to be done in horticultural crops and smaller-scale agriculture (Table 3). However, the need for green chemistry to replace fossil carbon-based chemistry may in future intensify the production of terpene-rich plants for flavour, fragrance, perfume, pesticide and organic solvent industries. Strip cropping these sVOC-rich plants with other major crops might allow development of some modern intercropping/trap cropping systems for pest control.

\section{Side effects, risks and benefits related to using biogenic sVOCs in agroecosystems}

One option for increasing biological pest resistance of crop plants in future might be through engineering plants with desired emission profiles. Techniques for this might even include genetic engineering (Schuman and Baldwin 2018). Risk assessment of genetically modified (GM) crop plants has been developed in recent years to minimise the unintended pleiotropic effects of transgenes and the harmful impact of these crops on humans and the environment (Houshyani et al. 2014). Efforts to intensify production of herbivore-induced VOCs and sVOCs in crop plants for better attraction of natural enemies of pests have included production of Arabidopsis Heynh. ex Holl \& Heynh. (Brassicaceae) lines with a mitochondrial targeted nerolidol synthase gene. In these transgenic plants, the variation in gene expression did not differ from gene expression variation occurring naturally in Arabidopsis (Houshyani et al. 2014). However, transcriptional identity of GM lines of an original isogenic variety in standardised environmental conditions does not always secure the situation in the field (Benevenuto et al. 2017). In pathway and proteome analyses of herbicide-tolerant maize, it was found that environment is the major source of variation followed by the genetic transformation factor. Drought and herbicide stress led to some differences in protein relative abundance and levels of some plant sVOCs such as MeJA and cinnamic acid (Benevenuto et al. 2017). The Bacillus thuringiensis (Bt) - toxin transgene in B. napus did not affect production of SQTs, but herbivore-induced production of the SQTs $\beta$-elemene and $(E, E)$ - $\alpha$-farnesene was reduced in $B t$-transgenic plants due to more limited foliar damage on these resistant plants, indicating again the strong biotic influence on VOC-mediated ecological interactions (Himanen et al. 2009).

An obvious risk of success of sVOC-based biocontrol strategies comes from the fact that most studies assessing the role and function of sVOCs for herbivorous and predatory/ parasitising arthropods have been done in the laboratory: a functional system showing excellent results in laboratory and greenhouse conditions might not work in the field in 


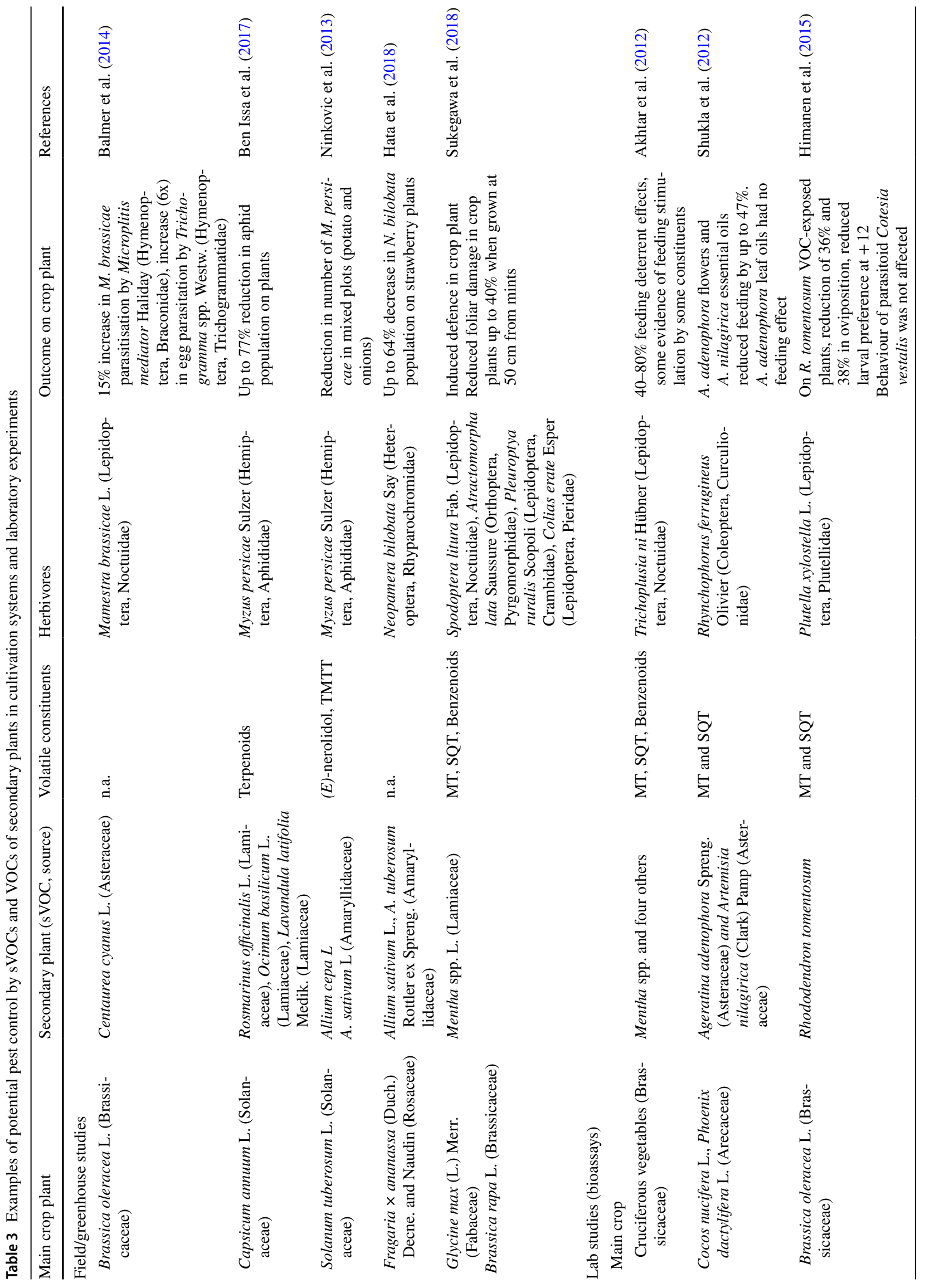


practical pest management situations. For example, aphids release the SQT $(E)$ - $\beta$-farnesene as an alarm pheromone, when attacked by natural enemies. This SQT acts as a repellent to other aphids, which avoid the plant, while also attracting aphid parasitoids. When a GM wheat variety with transgenic $(E)-\beta$-farnesene synthase was tested in the laboratory, aphid repellency and parasitoid attraction was excellent (Pickett and Khan 2016). However, field trials did not show any efficient aphid repellency (Bruce et al. 2015). It was expected that the constitutive expression and emission $(E)$ $\beta$-farnesene may not be appropriate for a pheromonal function, because aphids emit this SQT in natural conditions in short-term bursts when an aphid is attacked by a parasitoid (Pickett and Khan 2016). Another important reason for failure of field trials is the variation of natural insect densities that might influence the probability of parasitoids detecting SQT signals at low population densities (Bruce et al. 2015). Therefore, a proper efficiency assessment in natural field conditions is essential, before progressing in further integration of sVOC emitting secondary plants in ecologically intensified production systems such as intercropping.

In the context of VOC-based pest control strategies and their application in the future, climate change and variation in "natural conditions" globally should be considered due to the effects of the abiotic environment on VOC and sVOC production by plants. An elevating temperature has most consistently resulted in increased MT and SQT emission from plants (Peñuelas and Staudt 2010; Genard-Zielinski et al. 2018; Holopainen et al. 2018), while severe drought (Peñuelas and Staudt 2010; Saunier et al. 2017; GenardZielinski et al. 2018) and elevated $\mathrm{CO}_{2}$ (Peñuelas and Staudt 2010; Klaiber et al. 2013) have resulted in reduced VOC and sVOC emissions, although some crop plant growth phases may respond differently (Himanen et al. 2009; Nogues et al. 2015). It is noteworthy that we have rather limited knowledge of the environmental responsiveness of different VOC groups, while there are likely to be both synergistic and antagonistic effects on VOC emission and persistence by various biotic and abiotic stressors (Yuan et al. 2009). This responsiveness needs to be tested when developing VOCbased biocontrol solutions in order to be effective and resilient in future agriculture, while it is important to consider that regional conditions might well impact the efficacy.

Natural compounds can be as beneficial or harmful to human and cattle health as synthetically produced chemicals. However, common existence of biogenic VOCs in our environment suggests that humans have adapted to most of these compounds acquired, e.g. from the air or from sVOCrich crop plants used as spices. If using a known medicinal plant as a crop plant companion (Gahukar 2012), some of the specific sVOCs appearing in high concentrations can be toxic to humans. For example, the odour of $R$. tomentosum with very high concentrations of ledol in the air may 


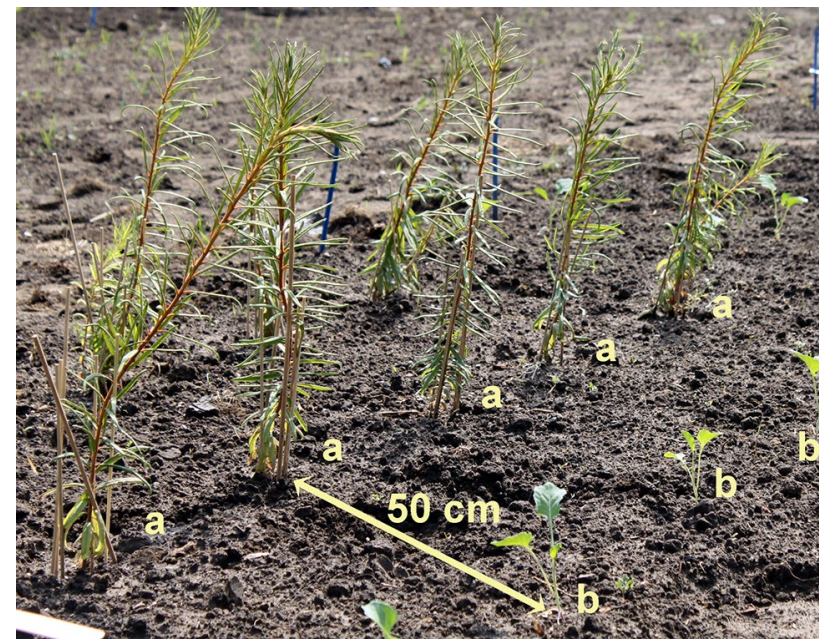

Fig. 4 Rhododendron tomentosum plants (a) grown from seeds planted as repellent/barrier plants in the margins of broccoli (Brassica oleracea L. var. italica), (b) field plots. R. tomentosum root system in Sphagnum peat maintain growth during growing season. Released sVOCs may provide environmental chemical camouflage to crop plants when sVOCs will adhere on foliage during colder temperatures in the evening and in the night. An arrow indicates the distance from a barrier plant to the closest crop plant

cause headache and nausea (Dampc and Luczkiewicz 2013). However, recent field experiments with $R$. tomentosum as a companion plant with broccoli (Fig. 4) have shown that ledol cannot be recovered in daytime VOC-sampling from broccoli plants, although $R$. tomentosum volatiles may influence herbivore densities on crop plants (Bui et al., unpublished). When using a perennial plant originating from peatland/forest habitats (such as $R$. tomentosum) in agricultural fields, the best growth response is achieved when seedlings are potted and grown in low-pH soil. Such companion/secondary planting could be a safe way to avoid the secondary plant from becoming a weed in agricultural fields.

Other risks relevant to using reactive organic compounds in agricultural fields could be related to the products of their reactions with atmospheric oxidants. Particularly, plants emitting more SQTs promote secondary organic aerosol (SOA) formation above vegetation (Faiola et al. 2018; Hellen et al. 2018). Herbivore feeding (Pinto et al. 2007) or herbivore stress simulated with elicitors (Joutsensaari et al. 2005) on Brassicaceous plants increased the proportion of SQTs in plant emissions and resulted in increased SOA formation (Joutsensaari et al. 2005). However, this risk might be lower than the risk caused by inhalation of anthropogenic aerosols including, e.g. smoke released by burning of fuels or aerosols released by spraying of synthetic pesticides (Coscolla et al. 2013).

When considering the benefits of using natural plants and their biogenic emissions in pest control, the proposed system has to be compared to current conventional crop production strategies. The extensive use of certain chemical pesticides with limited knowledge of their behaviour in natural and agroecosystems may lead to more strict regulations and banning of some compounds after use for several decades. With natural compounds, non-target effects need to be assessed as well, while their environmental persistence may be shorter. For example, synthetic neonicotinoids have been in common use for nearly three decades and their relationship with pollinator decline has been shown (e.g. Lämsä et al. 2018), but we have only started to understand plant surface and atmospheric behaviour of neonicotinoids in detail very recently (Finlayson-Pitts 2017). In the case of the neonicotinoid insecticide imidacloprid, the desnitro derivative formed photochemically in the biofilm on plant surfaces is more toxic than the parent compound (Aregahegn et al. 2017; Finlayson-Pitts 2017). Furthermore, degradation of this compound leads to formation of the important greenhouse gas, nitrous oxide $\left(\mathrm{N}_{2} \mathrm{O}\right)$. Global warming potential of $\mathrm{N}_{2} \mathrm{O}$ is 296-fold, when compared to $\mathrm{CO}_{2}$ in a 100 -year scale (Crutzen et al. 2008). It has been estimated that the release of $\mathrm{N}_{2} \mathrm{O}$ from neonicotinoids used in agriculture could be at the same level as the release of $\mathrm{N}_{2} \mathrm{O}$ from fertilisers used in agriculture (Finlayson-Pitts 2017). If we assume that the worldwide use of neonicotinoids could be replaced by using VOC-rich and sVOC-rich secondary plants and more intensive use of natural essential oils, it would mean a reduction in the climate warming effects of production and photochemical degradation of synthetic insecticides, and potentially a climate-cooling through increased natural VOC and sVOC emissions from agriculture. This is possible, because biogenic VOCs and sVOCs often participate in atmospheric SOA formation at regional and local scales (Joutsensaari et al. 2015; Zhao et al. 2017). SOA participates in cloud formation in the upper atmosphere and acts as a shield against warming effects of solar radiation (Paasonen et al. 2013). Furthermore, SOA in the lower atmosphere aids diffusion of solar radiation (Rap et al. 2018). Diffused solar light has a capacity to improve photosynthesis of plant canopies by reducing shaded parts within foliage and thus increase $\mathrm{CO}_{2}$ removal from the atmosphere (Rap et al. 2018). Transition from the use neonicotinoids to use of biogenic VOCs in sustainable pest management could be one potential effort to reduce the significant greenhouse gas emissions from agriculture and to improve natural processes to mitigate global warming (Reay et al. 2012).

\section{Conclusions}

The beneficial aspects of sVOCs of crop plants and secondary companion plants could have an important role in the development of more sustainable pest control methods for increasing crop production. The biogenic sVOCs in pest 
management may be a way to replace some synthetic pesticides and help secure the ecosystem services provided by insects such as natural biological control and pollination in the future. However, the natural adsorption-desorption cycle of sVOCs on crop plant surfaces still needs proper assessment for better understanding of its functionality under different climatic conditions. In addition, a greater research effort should be made into deciphering the potential of sVOCs for priming and inducing the chemical defences of crop plants and thus providing improved crop defence and tolerance against arthropod pests. For designing pestbuffering intercropping and companion cropping strategies relying on VOCs, it will be essential also to understand the trophic cascades and spatiotemporal aspects that jointly contribute to yielding and biocontrol efficacy.

Acknowledgements Open access funding provided by University of Eastern Finland (UEF) including Kuopio University Hospital.

Funding The funding was supported by Academy of Finland (Grant Nos. 278424 and 309425)

Open Access This article is distributed under the terms of the Creative Commons Attribution 4.0 International License (http://creativeco mmons.org/licenses/by/4.0/), which permits unrestricted use, distribution, and reproduction in any medium, provided you give appropriate credit to the original author(s) and the source, provide a link to the Creative Commons license, and indicate if changes were made.

\section{References}

Adebesin F, Widhalm JR, Boachon B, Lefevre F, Pierman B, Lynch JH, Alam I, Junqueira B, Benke R, Ray S, Porter JA, Yanagisawa M, Wetzstein HY, Morgan JA, Boutry M, Schuurink RC, Dudareva N (2017) Emission of volatile organic compounds from petunia flowers is facilitated by an $\mathrm{ABC}$ transporter. Science 356:1386-1388

Akhtar Y, Pages E, Stevens A, Bradbury R, da Camara CAG, Isman MB (2012) Effect of chemical complexity of essential oils on feeding deterrence in larvae of the cabbage looper. Physiol Entomol 37:81-91

Altieri MA, Funes-Monzote FR, Petersen P (2012) Agroecologically efficient agricultural systems for smallholder farmers: contributions to food sovereignty. Agron Sustain Dev 32:1-13

Andersen MM, Landes X, Xiang W, Anyshchenko A, Falhof J, Osterberg JT, Olsen LI, Edenbrandt AK, Vedel SE, Thorsen BJ, Sandoe P, Gamborg C, Kappel K, Palmgren MG (2015) Feasibility of new breeding techniques for organic farming. Trends Plant Sci 20:426-434

Aregahegn KZ, Shemesh D, Gerber RB, Finlayson-Pitts BJ (2017) Photochemistry of thin solid films of the neonicotinoid imidacloprid on surfaces. Environ Sci Technol 51:2660-2668

Arimura G, Ozawa R, Shimoda T, Nishioka T, Boland W, Takabyashi $\mathrm{J}$ (2000) Herbivory-induced volatiles elicit defence genes in lima bean leaves. Nature 406:512-515

Arimura G, Huber DPW, Bohlmann J (2004) Forest tent caterpillars (Malacosoma disstria) induce local and systemic diurnal emissions of terpenoid volatiles in hybrid poplar (Populus trichocarpa $\mathrm{x}$ deltoides): cDNA cloning, functional characterization, and patterns of gene expression of (-)-germacrene D synthase, PtdTPS1. Plant J 37:603-616

Arimura G, Garms S, Maffei M, Bossi S, Schulze B, Leitner M, Mithofer A, Boland W (2008) Herbivore-induced terpenoid emission in Medicago truncatula: concerted action of jasmonate, ethylene and calcium signaling. Planta 227:453-464

Baldwin I, Schultz J (1983) Rapid changes in tree leaf chemistry induced by damage-evidence for communication between plants. Science 221:277-279

Balmer O, Geneau CE, Belz E, Weishaupt B, Foerderer G, Moos S, Ditner N, Juric I, Luka H (2014) Wildflower companion plants increase pest parasitation and yield in cabbage fields: experimental demonstration and call for caution. Biol Control 76:19-27

Bamberger I, Hoertnagl L, Ruuskanen TM, Schnitzhofer R, Mueller M, Graus M, Karl T, Wohlfahrt G, Hansel A (2011) Deposition fluxes of terpenes over grassland. J Geophys Res Atmos 116:D14305

Ben Issa R, Gautier H, Gomez L (2017) Influence of neighbouring companion plants on the performance of aphid populations on sweet pepper plants under greenhouse conditions. Agric For Entomol 19:181-191

Benevenuto RF, Agapito-Tenfen SZ, Vilperte V, Wikmark O, van Rensburg PJ, Nodari RO (2017) Molecular responses of genetically modified maize to abiotic stresses as determined through proteomic and metabolomic analyses. PLoS ONE 12:e0173069

Bezerra LDA, Mangabeira PAO, de Oliveira RA, Costa LCDB, Da Cunha M (2018) Leaf blade structure of Verbesina macrophylla (Cass.) F. S. Blake (Asteraceae): ontogeny, duct secretion mechanism and essential oil composition. Plant Biol 20:433-443

Blande JD, Holopainen JK, Li T (2010) Air pollution impedes plant-toplant communication by volatiles RID B-1656-2008. Ecol Lett 13:1172-1181

Blande JD, Holopainen JK, Niinemets U (2014) Plant volatiles in polluted atmospheres: stress responses and signal degradation. Plant Cell Environ 37:1892-1904

Bohlmann J, Keeling CI (2008) Terpenoid biomaterials. Plant J 54:656-669

Borghi M, Fernie AR, Schiestl FP, Bouwmeester HJ (2017) The sexual advantage of looking, smelling, and tasting good: the metabolic network that produces signals for pollinators. Trends Plant Sci 22:338-350

Bottini A, Arfagnoli D, Delgado L, Dev V, Duong S, Kelley C, Keyer R, Raffel R, Joshi P, Mathela C (1987) Sesquiterpene alcohols from Hedychium spicatum Var acuminatum. J Nat Prod 50:732-734

Brooker RW, Bennett AE, Cong W, Daniell TJ, George TS, Hallett PD, Hawes C, Iannetta PPM, Jones HG, Karley AJ, Li L, McKenzie BM, Pakeman RJ, Paterson E, Schoeb C, Shen J, Squire G, Watson CA, Zhang C, Zhang F, Zhang J, White PJ (2015) Improving intercropping: a synthesis of research in agronomy, plant physiology and ecology. New Phytol 206:107-117

Bruce TJA, Aradottir GI, Smart LE, Martin JL, Caulfield JC, Doherty A, Sparks CA, Woodcock CM, Birkett MA, Napier JA, Jones HD, Pickett JA (2015) The first crop plant genetically engineered to release an insect pheromone for defence. Sci Rep 5:11183

Catola S, Centritto M, Cascone P, Ranieri A, Loreto F, Calamai L, Balestrini R, Guerrieri E (2018) Effects of single or combined water deficit and aphid attack on tomato volatile organic compound (VOC) emission and plant-plant communication. Environ Exp Bot 153:54-62

Choh Y, Shimoda T, Ozawa R, Dicke M, Takabayashi J (2004) Exposure of lima bean leaves to volatiles from herbivore-induced conspecific plants results in emission of carnivore attractants: active or passive process? J Chem Ecol 30:1305-1317

Ciccioli P, Brancaleoni E, Frattoni M, Di Palo V, Valentini R, Tirone G, Seufert G, Bertin N, Hansen U, Csiky O, Lenz R, Sharma 
M (1999) Emission of reactive terpene compounds from orange orchards and their removal by within-canopy processes. J Geophys Res Atmos 104:8077-8094

Cook SM, Khan ZR, Pickett JA (2007) The use of push-pull strategies in integrated pest management. Annu Rev Entomol 52:375-400

Copolovici L, Niinemets U (2015) Temperature dependencies of Henry's law constants for different plant sesquiterpenes. Chemosphere 138:751-757

Copolovici L, Filella I, Llusia J, Niinemets U, Penuelas J (2005) The capacity for thermal protection of photosynthetic electron transport varies for different monoterpenes in Quercus ilex. Plant Physiol 139:485-496

Coppola M, Manco E, Vitiello A, Di Lelio I, Giorgini M, Rao R, Pennacchio F, Digilio MC (2018) Plant response to feeding aphids promotes aphid dispersal. Entomol Exp Appl 166:386-394

Coscolla C, Hart E, Pastor A, Yusa V (2013) LC-MS characterization of contemporary pesticides in PM10 of Valencia Region, Spain. Atmos Environ 77:394-403

Cotes B, Ramert B, Nilsson U (2018) A first approach to pest management strategies using trap crops in organic carrot fields. Crop Prot 112:141-148

Crutzen PJ, Mosier AR, Smith KA, Winiwarter W (2008) N2O release from agro-biofuel production negates global warming reduction by replacing fossil fuels. Atmos Chem Phys 8:389-395

Curtis J (1860) Farm insects. Blackie \& Son, Glasgow

da Silva Rodrigues-Correa KC, de Lima JC, Fett-Neto AG (2013) Oleoresins from pine: production and industrial uses. In: Ramawat KG, Merillon J (eds) Natural products. Springer, Berlin, pp 4037-4060

Dampc A, Luczkiewicz M (2013) Rhododendron tomentosum (Ledum palustre). A review of traditional use based on current research. Fitoterapia 85:130-143

Delory BM, Delaplace P, Fauconnier M, du Jardin P (2016) Root-emitted volatile organic compounds: can they mediate belowground plant-plant interactions? Plant Soil 402:1-26

Demasi S, Caser M, Lonati M, Cioni PL, Pistelli L, Najar B, Scariot V (2018) Latitude and altitude influence secondary metabolite production in peripheral alpine populations of the mediterranean species Lavandula angustifolia mill. Front Plant Sci 9:983

Donahue NM, Chuang W, Epstein SA, Kroll JH, Worsnop DR, Robinson AL, Adams PJ, Pandis SN (2013) Why do organic aerosols exist? Understanding aerosol lifetimes using the two-dimensional volatility basis set. Environ Chem 10:151-157

Egigu MC, Ibrahim MA, Yahya A, Holopainen JK (2010) Yeheb (Cordeauxia edulis) extract deters feeding and oviposition of Plutella xylostella and attracts its natural enemy. Biocontrol 55:613-624

Egonyu JP (2013) Diel patterns of mating, oviposition and feeding in the coconut bug, Pseudotheraptus wayi Brown (Heteroptera: Coreidae). Afr Entomol 21:103-107

Eigenbrode SD, Birch ANE, Lindzey S, Meadow R, Snyder WE (2016) REVIEW: a mechanistic framework to improve understanding and applications of push-pull systems in pest management. $\mathbf{J}$ Appl Ecol 53:202-212

Erb M (2018) Volatiles as inducers and suppressors of plant defense and immunity-origins, specificity, perception and signaling. Curr Opin Plant Biol 44:117-121

Faiola CL, Buchholz A, Kari E, Yli-Pirilä P, Holopainen JK, Kivimäenpää M, Miettinen P, Worsnop DR, Lehtinen KEJ, Guenther AB, Virtanen A (2018) Terpene Composition Complexity Controls Secondary Organic Aerosol Yields from Scots Pine Volatile Emissions. Sci Rep 8:3053

Finlayson-Pitts BJ (2017) Introductory lecture: atmospheric chemistry in the Anthropocene. Faraday Discuss 200:11-58
Francis C, Lieblein G, Gliessman S, Breland T, Creamer N, Harwood R, Salomonsson L, Helenius J, Rickerl D, Salvador R, Wiedenhoeft M, Simmons S, Allen P, Altieri M, Flora C, Poincelot R (2003) Agroecology: the ecology of food systems. J Sustain Agric 22:99-118

Frenzke L, Lederer A, Malanin M, Eichhorn K, Neinhuis C, Voigt D (2016) Plant pressure sensitive adhesives: similar chemical properties in distantly related plant lineages. Planta 244:154

Frost CJ, Appel M, Carlson JE, De Moraes CM, Mescher MC, Schultz JC (2007) Within-plant signalling via volatiles overcomes vascular constraints on systemic signalling and primes responses against herbivores. Ecol Lett 10:490-498

Fuentes JD, Chamecki M, Roulston T, Chen B, Pratt KR (2016) Air pollutants degrade floral scents and increase insect foraging times. Atmos Environ 141:361-374

Gahukar RT (2012) Evaluation of plant-derived products against pests and diseases of medicinal plants: a review. Crop Prot 42:202-209

Garcia L, Celette F, Gary C, Ripoche A, Valdes-Gomez H, Metay A (2018) Management of service crops for the provision of ecosystem services in vineyards: a review. Agric Ecosyst Environ 251:158-170

Genard-Zielinski A, Boissard C, Ormeno E, Lathiere J, Reiter IM, Wortham H, Orts J, Temime-Roussel B, Guenet B, Bartsch S, Gauquelin T, Fernandez C (2018) Seasonal variations of Quercus pubescens isoprene emissions from an in natura forest under drought stress and sensitivity to future climate change in the Mediterranean area. Biogeosciences 15:4711-4730

Ghirardo A, Koch K, Taipale R, Zimmer I, Schnitzler J, Rinne J (2010) Determination of de novo and pool emissions of terpenes from four common boreal/alpine trees by $13 \mathrm{CO}(2)$ labelling and PTRMS analysis. Plant Cell Environ 33:781-792

Giron D, Dubreuil G, Bennett A, Dedeine F, Dicke M, Dyer LA, Erb M, Harris MO, Huguet E, Kaloshian I, Kawakita A, LopezVaamonde C, Palmer TM, Petanidou T, Poulsen M, Salle A, Simon J, Terblanche JS, Thiery D, Whiteman NK, Woods HA, Pincebourde S (2018) Promises and challenges in insect-plant interactions. Entomol Exp Appl 166:319-343

Giron-Calva PS, Li T, Blande JD (2016) Plant-plant interactions affect the susceptibility of plants to oviposition by pests but are disrupted by ozone pollution. Agric Ecosyst Environ 233:352-360

Giron-Calva PS, Li T, Blande JD (2017) Volatile-mediated interactions between cabbage plants in the field and the impact of ozone pollution. J Chem Ecol 43:339-350

Glas JJ, Schimmel BCJ, Alba JM, Escobar-Bravo R, Schuurink RC, Kant MR (2012) Plant glandular trichomes as targets for breeding or engineering of resistance to herbivores. Int J Mol Sci 13:17077-17103

Graf B, Hoepli HU, Hoehn H (2015) Temperature effects on reproduction and adult lifespan of the smaller fruit tortrix, Grapholita lobarzewskii. Entomol Exp Appl 154:71-77

Greenberg SM, Armstrong JS, Sétamou M, Sappington TW, Coleman RJ, Liu TX (2006) Circadian rhythms of feeding, oviposition, and emergence of the boll weevil (Coleoptera: Curculionidae). Insect Sci 13:461-467

Gregg PC, Del Socorro AP, Landolt PJ (2018) Advances in attractand-kill for agricultural pests: beyond pheromones. Annu Rev Entomol 63 63:453-470

Haddad NM, Crutsinger GM, Gross K, Haarstad J, Tilman D (2011) Plant diversity and the stability of foodwebs. Ecol Lett 14:42-46

Hashidoko Y, Tahara S, Mizutani J (1994) 6 Sesquiterpenoids from glandular trichome exudates of rosa-rugosa. Phytochemistry 35:325-329

Hata FT, Ventura MU, Bega VL, Camacho IM, de Paula MT (2018) Chinese chives and garlic in intercropping in strawberry high tunnels for Neopamera bilobata Say (Hemiptera: 
Rhyparochromidae) control. Bull Entomol Res. https://doi. org/10.1017/S0007485318000299

Heijari J, Blande JD, Holopainen JK (2011) Feeding of large pine weevil on Scots pine stem triggers localised bark and systemic shoot emission of volatile organic compounds. Environ Exp Bot 71:390-398

Heil M (2014) Herbivore- induced plant volatiles: targets, perception and unanswered questions. New Phytol 204:297-306

Heil M, Karban R (2010) Explaining evolution of plant communication by airborne signals. Trends Ecol Evol 25:137-144

Heil M, Silva Bueno JC (2007) Within-plant signaling by volatiles leads to induction and priming of an indirect plant defense in nature. Proc Natl Acad Sci USA 104:5467-5472

Hellen H, Praplan AP, Tykkä T, Ylivinkka I, Vakkari V, Bäck J, Petäjä T, Kulmala M, Hakola H (2018) Long-term measurements of volatile organic compounds highlight the importance of sesquiterpenes for the atmospheric chemistry of a boreal forest. Atmos Chem Phys 18:13839-13863

Hiltpold I, Turlings TCJ (2012) Manipulation of chemically mediated interactions in agricultural soils to enhance the control of crop pests and to improve crop yield. J Chem Ecol 38:641-650

Himanen SJ, Nerg A, Nissinen A, Pinto DM, Stewart CN Jr, Poppy GM, Holopainen JK (2009) Effects of elevated carbon dioxide and ozone on volatile terpenoid emissions and multitrophic communication of transgenic insecticidal oilseed rape (Brassica napus). New Phytol 181:174-186

Himanen SJ, Blande JD, Klemola T, Pulkkinen J, Heijari J, Holopainen JK (2010) Birch (Betula spp.) leaves adsorb and re-release volatiles specific to neighbouring plants-a mechanism for associational herbivore resistance? New Phytol 186:722-732

Himanen SJ, Bui TNT, Maja MM, Holopainen JK (2015) Utilizing associational resistance for biocontrol: impacted by temperature, supported by indirect defence. Bmc Ecology 15:16

Hokkanen H (1991) Trap cropping in pest-management. Annu Rev Entomol 36:119-138

Hokkanen HMT, Menzler-Hokkanen I (2018) Urgent need to develop ecostacking techniques to enhance ecosystem services in cropping systems. Arthropod-Plant Interact 12:477-482

Holopainen JK, Blande JD (2013) Where do herbivore-induced plant volatiles go? Front Plant Sci 4:185

Holopainen JK, Gershenzon J (2010) Multiple stress factors and the emission of plant VOCs. Trends Plant Sci 15:176-184

Holopainen JK, Kivimaenpaa M, Nizkorodov SA (2017) Plant-derived secondary organic material in the air and ecosystems. Trends Plant Sci 22:744-753

Holopainen JK, Virjamo V, Ghimire RP, Blande JD, Julkunen-Tiitto R, Kivimaenpaa M (2018) Climate change effects on secondary compounds of forest trees in the northern hemisphere. Front Plant Sci 9:1445

Horstmann M, McLachlan M (1998) Atmospheric deposition of semivolatile organic compounds to two forest canopies. Atmos Environ 32:1799-1809

Houshyani B, van der Krol AR, Bino RJ, Bouwmeester HJ (2014) Assessment of pleiotropic transcriptome perturbations in Arabidopsis engineered for indirect insect defence. BMC Plant Biol 14:170

Ibrahim MA, Kainulainen P, Aflatuni A, Tiilikkala K, Holopainen JK (2001) Insecticidal, repellent, antimicrobial activity and phytotoxicity of essential oils: With special reference to limonene and its suitability for control of insect pests. Agric Food Sci Finland 10:243-259

Ibrahim MA, Oksanen EJ, Holopainen JK (2004) Effects of limonene on the growth and physiology of cabbage (Brassica oleracea $\mathrm{L}$ ) and carrot (Daucus carota L) plants. J Sci Food Agric 84:1319-1326
Ibrahim M, Nissinen A, Holopainen J (2005) Response of Plutella xylostella and its parasitoid Cotesia plutellae to volatile compounds. J Chem Ecol 31:1969-1984

Jaenson T, Palsson K, Borg-Karlson A (2005) Evaluation of extracts and oils of tick-repellent plants from Sweden. Med Vet Entomol 19:345-352

Jardine K, Serrano AY, Arneth A, Abrell L, Jardine A, van Haren J, Artaxo P, Rizzo LV, Ishida FY, Karl T, Kesselmeier J, Saleska S, Huxman T (2011) Within-canopy sesquiterpene ozonolysis in Amazonia. J Geophys Res-Atmos 116:D19301

Jesionek A, Kokotkiewicz A, Wlodarska P, Zabiegala B, Bucinski A, Luczkiewicz M (2017) Bioreactor shoot cultures of Rhododendron tomentosum (Ledum palustre) for a large-scale production of bioactive volatile compounds. Plant Cell Tissue Organ Cult 131:51-64

Jin J, Panicker D, Wang Q, Kim MJ, Liu J, Yin J, Wong L, Jang I, Chua N, Sarojam R (2014) Next generation sequencing unravels the biosynthetic ability of Spearmint (Mentha spicata) peltate glandular trichomes through comparative transcriptomics. BMC Plant Biol 14:292

Joutsensaari J, Loivamaki M, Vuorinen T, Miettinen P, Nerg AM, Holopainen JK, Laaksonen A (2005) Nanoparticle formation by ozonolysis of inducible plant volatiles. Atmos Chem Phys 5:1489-1495

Joutsensaari J, Yli-Pirilä P, Korhonen H, Arola A, Blande JD, Heijari J, Kivimäenpää M, Mikkonen S, Hao L, Miettinen P, LyytikäinenSaarenmaa P, Faiola CL, Laaksonen A, Holopainen JK (2015) Biotic stress accelerates formation of climate-relevant aerosols in boreal forests. Atmos Chem Phys 15:12139-12157

Karban R, Maron J (2002) The fitness consequences of interspecific eavesdropping between plants. Ecology 83:1209-1213

Karl T, Guenther A, Turnipseed A, Patton EG, Jardine K (2008) Chemical sensing of plant stress at the ecosystem scale. Biogeosciences 5:1287-1294

Kasal-Slavik T, Eschweiler J, Kleist E, Mumm R, Goldbach HE, Schouten A, Wildt J (2017) Early biotic stress detection in tomato (Solanum lycopersicum) by BVOC emissions. Phytochemistry 144:180-188

Keeling CI, Bohlmann J (2006) Diterpene resin acids in conifers. Phytochemistry 67:2415-2423

Kessler A, Kalske A (2018) Plant secondary metabolite diversity and species interactions. Annu Rev Ecol Evol Syst 49 49:115-138

Khan ZR, Midega CAO, Bruce TJA, Hooper AM, Pickett JA (2010) Exploiting phytochemicals for developing a 'push-pull' crop protection strategy for cereal farmers in Africa. J Exp Bot 61:4185-4196

Klaiber J, Najar-Rodriguez AJ, Piskorski R, Dorn S (2013) Plant acclimation to elevated $\mathrm{CO} 2$ affects important plant functional traits, and concomitantly reduces plant colonization rates by an herbivorous insect. Planta 237:29-42

Kolosova N, Sherman D, Karlson D, Dudareva N (2001) Cellular and subcellular localization of S-adenosyl-L-methionine: benzoic acid carboxyl methyltransferase, the enzyme responsible for biosynthesis of the volatile ester methylbenzoate in snapdragon flowers. Plant Physiol 126:956-964

Kost C, Heil M (2006) Herbivore-induced plant volatiles induce an indirect defence in neighbouring plants. J Ecol 94:619-628

Kovacs-Hostyanszki A, Espindola A, Vanbergen AJ, Settele J, Kremen C, Dicks LV (2017) Ecological intensification to mitigate impacts of conventional intensive land use on pollinators and pollination. Ecol Lett 20:673-689

Kremer D, Cepo DV, Dunkic V, Mueller ID, Kosalec I, Bezic N, Stabentheiner E (2013) Phytochemical and Micromorphological Traits of Geranium dalmaticum and G. macrorrhizum (Geraniaceae). Nat Prod Commun 8:645-650 
Krimmel BA, Pearse IS (2013) Sticky plant traps insects to enhance indirect defence. Ecol Lett 16:219-224

Kumar P, Mishra S, Malik A, Satya S (2011) Insecticidal properties of Mentha species: a review. Ind Crop Prod 34:802-817

Lämsä J, Kuusela E, Tuomi J, Juntunen S, Watts PC (2018) Low dose of neonicotinoid insecticide reduces foraging motivation of bumblebees. Proc R Soc B-Biol Sci 285:20180506

Lamy F, Dugravot S, Cortesero AM, Chaminade V, Faloya V, Poinsot D (2018) One more step toward a push-pull strategy combining both a trap crop and plant volatile organic compounds against the cabbage root fly Delia radicum. Environ Sci Pollut Res 25:29868-29879

Laothawornkitkul J, Taylor JE, Paul ND, Hewitt CN (2009) Biogenic volatile organic compounds in the Earth system. New Phytol 183:27-51

Lee JHJ, Jayaprakasha GK, Avila CA, Crosby KM, Patil BS (2019) Metabolomic studies of volatiles from tomatoes grown in net-house and open-field conditions. Food Chem. https://doi. org/10.1016/j.foodchem.2018.09.091

Leitner M, Boland W, Mithofer A (2005) Direct and indirect defences induced by piercing-sucking and chewing herbivores in Medicago truncatula. New Phytol 167:597-606

Li T, Blande JD (2015) Associational susceptibility in broccoli: mediated by plant volatiles, impeded by ozone. Global Change Biol 21:1993-2004

Li S, Tosens T, Harley PC, Jiang Y, Kanagendran A, Grosberg M, Jaamets K, Niinemets U (2018) Glandular trichomes as a barrier against atmospheric oxidative stress: relationships with ozone uptake, leaf damage, and emission of LOX products across a diverse set of species. Plant Cell Environ 41:1263-1277

Liebmann J, Karu E, Sobanski N, Schuladen J, Ehn M, Schallhart S, Quelever L, Hellen H, Hakola H, Hoffmann T, Williams J, Fischer H, Lelieveld J, Crowley JN (2018) Direct measurement of $\mathrm{NO}_{3}$ radical reactivity in a boreal forest. Atmos Chem Phys 18:3799-3815

Lopes T, Hatt S, Xu Q, Chen J, Liu Y, Francis F (2016) Wheat (Triticum aestivum $\mathrm{L}$.)-based intercropping systems for biological pest control. Pest Manag Sci 72:2193-2202

LoPresti EF (2016) Chemicals on plant surfaces as a heretofore unrecognized, but ecologically informative, class for investigations into plant defence. Biol Rev 91:1102-1117

LoPresti E, Krimmel B, Pearse IS (2018) Entrapped carrion increases indirect plant resistance and intra-guild predation on a sticky tarweed. Oikos 127:1033-1044

Loreto F, Schnitzler J (2010) Abiotic stresses and induced BVOCs. Trends Plant Sci 15:154-166

Lucattini L, Poma G, Covaci A, de Boer J, Lamoree MH, Leonards PEG (2018) A review of semi-volatile organic compounds (SVOCs) in the indoor environment: occurrence in consumer products, indoor air and dust. Chemosphere 201:466-482

Matsui K, Sugimoto K, Mano J, Ozawa R, Takabayashi J (2012) Differential metabolisms of green leaf volatiles in injured and intact parts of a wounded leaf meet distinct ecophysiological requirements. PLoS ONE 7:e36433

Mauchline AL, Cook SM, Powell W, Osborne JL (2013) Effects of non-host plant odour on Meligethes aeneus during immigration to oilseed rape. Entomol Exp Appl 146:313-320

McDowell ET, Kapteyn J, Schmidt A, Li C, Kang J, Descour A, Shi F, Larson M, Schilmiller A, An L, Jones AD, Pichersky E, Soderlund CA, Gang DR (2011) Comparative Functional Genomic Analysis of Solanum Glandular Trichome Types. Plant Physiol 155:524-539

Messina P, Lathiere J, Sindelarova K, Vuichard N, Granier C, Ghattas J, Cozic A, Hauglustaine DA (2016) Global biogenic volatile organic compound emissions in the ORCHIDEE and MEGAN models and sensitivity to key parameters. Atmos Chem Phys 16:14169-14202

Mofikoya AO, Kim TH, El-Raheem AMA, Blande JD, Kivimäenpää M, Holopainen JK (2017) Passive adsorption of volatile monoterpene in pest control: aided by proximity and disrupted by ozone. J Agric Food Chem 65:9579-9586

Mofikoya AO, Kivimäenpää M, Blande JD, Holopainen JK (2018a) Ozone disrupts adsorption of Rhododendron tomentosum volatiles to neighbouring plant surfaces, but does not disturb herbivore repellency. Environ Pollut 240:775-780

Mofikoya AO, Miura K, Ghimire RP, Blande JD, Kivimäenpää M, Holopainen T, Holopainen JK (2018b) Understorey Rhododendron tomentosum and leaf trichome density affect mountain birch VOC emissions in the subarctic. Sci Rep 8:13261

Muravnik LE, Kostina OV, Shavarda AL (2016) Glandular trichomes of Tussilago Farfara (Senecioneae, Asteraceae). Planta 244:737-752

Murungi LK, Kirwa H, Salifu D, Torto B (2016) Opposing roles of foliar and glandular trichome volatile components in cultivated nightshade interaction with a specialist herbivore. PLoS ONE 11:e0160383

Mutisya S, Saidi M, Opiyo A, Ngouajio M, Martin T (2016) Synergistic effects of Agronet covers and companion cropping on reducing whitefly infestation and improving yield of open field-grown tomatoes. Agronomy-Basel 6:42

Niinemets U (2018) Storage of defense metabolites in the leaves of Myrtaceae: news of the eggs in different baskets. Tree Physiol 38:1445-1450

Niinemets U, Fares S, Harley P, Jardine KJ (2014) Bidirectional exchange of biogenic volatiles with vegetation: emission sources, reactions, breakdown and deposition. Plant Cell Environ 37:1790-1809

Ninkovic V, Dahlin I, Vucetic A, Petrovic-Obradovic O, Glinwood R, Webster B (2013) Volatile exchange between undamaged plants-a new mechanism affecting insect orientation in intercropping. PLoS ONE 8:e69431

Ninkovic V, Markovic D, Dahlin I (2016) Decoding neighbour volatiles in preparation for future competition and implications for tritrophic interactions. Perspect Plant Ecol Evol Syst 23:11-17

Noe SM, Copolovici L, Niinemets U, Vaino E (2008) Foliar limonene uptake scales positively with leaf lipid content: "non-emitting" species absorb and release monoterpenes. Plant Biol 10:129-137

Nogues I, Medori M, Calfapietra C (2015) Limitations of monoterpene emissions and their antioxidant role in Cistus sp under mild and severe treatments of drought and warming. Environ Exp Bot 119:76-86

Orre-Gordon GUS, Wratten SD, Jonsson M, Simpson M, Hale R (2013) 'Attract and reward': combining a herbivore-induced plant volatile with floral resource supplementation-multi-trophic level effects. Biol Control 64:106-115

Oyama-Okubo N (2012) Analysis and classification of emitted scent compounds in leaves of Mentha cultivars. Bull Natl Inst Floric Sci 12:103-112

Paasonen P, Asmi A, Petaja T, Kajos MK, Aijala M, Junninen H, Holst T, Abbatt JPD, Arneth A, Birmili W, van Hamed A, Hoffer A, Laakso L, Laaksonen A, Richard Leaitch W, Plass-Dulmer C, Pryor SC, Raisanen P, Swietlicki E, Wiedensohler A, Worsnop DR, Kerminen V, Kulmala M (2013) Warming-induced increase in aerosol number concentration likely to moderate climate change. Nat Geosci 6:438-442

Palmgren MG, Edenbrandt AK, Vedel SE, Andersen MM, Landes X, Osterberg JT, Falhof J, Olsen LI, Christensen SB, Sandoe P, Gamborg C, Kappel K, Thorsen BJ, Pagh P (2015) Are we ready for back-to-nature crop breeding? Trends Plant Sci 20:155-164 
Parolin P, Bresch C, Desneux N, Brun R, Bout A, Boll R, Poncet C (2012) Secondary plants used in biological control: a review. Int J Pest Manage 58:91-100

Peñuelas J, Staudt M (2010) BVOCs and global change. Trends Plant Sci 15:133-144

Piazza LA, Lopez D, Silva MP, Lopez Rivilli MJ, Tourn MG, Cantero JJ, Scopel AL (2018) Volatiles and nonvolatiles in Flourensia campestris Griseb. (Asteraceae), how much do capitate glandular trichomes matter? Chem Biodivers 15:e1700511

Pichersky E, Raguso RA (2018) Why do plants produce so many terpenoid compounds? New Phytol 220:692-702. https://doi. org/10.1111/nph.14178

Pickett JA, Khan ZR (2016) Plant volatile-mediated signalling and its application in agriculture: successes and challenges. New Phytol 212:856-870

Pinto DM, Blande JD, Nykanen R, Dong WX, Nerg AM, Holopainen JK (2007) Ozone degrades common herbivore-induced plant volatiles: does this affect herbivore prey location by predators and parasitoids? J Chem Ecol 33:683-694

Pollmann J, Ortega J, Helmig D (2005) Analysis of atmospheric sesquiterpenes: sampling losses and mitigation of ozone interferences. Environ Sci Technol 39:9620-9629

Ponzio C, Gols R, Pieterse CMJ, Dicke M (2013) Ecological and phytohormonal aspects of plant volatile emission in response to single and dual infestations with herbivores and phytopathogens. Funct Ecol 27:587-598

Potting R, Perry J, Powell W (2005) Insect behavioural ecology and other factors affecting the control efficacy of agro-ecosystern diversification strategies. Ecol Model 182:199-216

Poveda K, Isabel Gomez M, Martinez E (2008) Diversification practices: their effect on pest regulation and production. Rev Colomb Entomol 34:131-144

Rap A, Scott CE, Reddington CL, Mercado L, Ellis RJ, Garraway S, Evans MJ, Beerling DJ, MacKenzie AR, Hewitt CN, Spracklen DV (2018) Enhanced global primary production by biogenic aerosol via diffuse radiation fertilization. Nat Geosci 11:640-644

Rasmann S, Kollner T, Degenhardt J, Hiltpold I, Toepfer S, Kuhlmann U, Gershenzon J, Turlings T (2005) Recruitment of entomopathogenic nematodes by insect-damaged maize roots. Nature 434:732-737

Ratnadass A, Fernandes P, Avelino J, Habib R (2012) Plant species diversity for sustainable management of crop pests and diseases in agroecosystems: a review. Agron Sustain Dev 32:273-303

Reay DS, Davidson EA, Smith KA, Smith P, Melillo JM, Dentener F, Crutzen PJ (2012) Global agriculture and nitrous oxide emissions. Nat Clim Chang 2:410-416

Salamanca J, Souza B, Rodriguez-Saona C (2018) Cascading effects of combining synthetic herbivore-induced plant volatiles with companion plants to manipulate natural enemies in an agroecosystem. Pest Manag Sci 74:2133-2145

Sambaraju KR, Donelson SL, Bozic J, Phillips TW (2016) Oviposition by Female Plodia interpunctella (Lepidoptera: Pyralidae): description and time budget analysis of behaviors in laboratory studies. Insects 7:4

Sarkar CS, Wang E, Wu S, Lei Z (2018) Application of trap cropping as companion plants for the management of agricultural pests: a review. Insects 9(4):128

Saunier A, Ormeno E, Boissard C, Wortham H, Temime-Roussel B, Lecareux C, Armengaud A, Fernandez C (2017) Effect of midterm drought on Quercus pubescens BVOCs' emission seasonality and their dependency on light and/or temperature. Atmos Chem Phys 17:7555-7566

Schaub A, Blande JD, Graus M, Oksanen E, Holopainen JK, Hansel A (2010) Real-time monitoring of herbivore induced volatile emissions in the field. Physiol Plantarum 138:123-133
Schiestl FP (2010) The evolution of floral scent and insect chemical communication. Ecol Lett 13:643-656

Schilmiller A, Shi F, Kim J, Charbonneau AL, Holmes D, Jones AD, Last RL (2010) Mass spectrometry screening reveals widespread diversity in trichome specialized metabolites of tomato chromosomal substitution lines. Plant J 62:391-403

Schuman MC, Baldwin IT (2018) Field studies reveal functions of chemical mediators in plant interactions. Chem Soc Rev 47:5338-5353

Shelton A, Nault B (2004) Dead-end trap cropping: a technique to improve management of the diamondback moth, Plutella xylostella (Lepidoptera: Plutellidae). Crop Prot 23:497-503

Shukla P, Vidyasagar PSPV, Aldosari SA, Abdel-Azim M (2012) Antifeedant activity of three essential oils against the red palm weevil, Rhynchophorus ferrugineus. Bull Insectol 65:71-76

Simmons A, Gurr G (2005) Trichomes of Lycopersicon species and their hybrids: effects on pests and natural enemies. Agric For Entomol 7:265-276

Song B, Jiao H, Tang G, Yao Y (2014) Combining repellent and attractive aromatic plants to enhance biological control of three tortricid species (Lepidoptera: Tortricidae) in an Apple Orchard. Fla Entomol 97:1679-1689

Spielmann FM, Langebner S, Ghirardo A, Hansel A, Schnitzler J, Wohlfahrt G (2017) Isoprene and alpha-pinene deposition to grassland mesocosms. Plant Soil 410:313-322

Stenberg JA, Heil M, Ahman I, Bjorkman C (2015) Optimizing crops for biocontrol of pests and disease. Trends Plant Sci 20:698-712

Stern VM, Mueller A, Sevacher V, Way M (1969) Lygus bug control in cotton through alfalfa interplanting. Calif Agric 23:8-10

Sukegawa S, Shiojiri K, Higami T, Suzuki S, Arimura G (2018) Pest management using mint volatiles to elicit resistance in soy: mechanism and application potential. Plant J 96:910-920

Synowiec A, Kalemba D, Drozdek E, Bocianowski J (2017) Phytotoxic potential of essential oils from temperate climate plants against the germination of selected weeds and crops. J Pest Sci 90:407-419

Szafranek B, Chrapkowska K, Waligora D, Palavinskas R, Banach A, Szafranek J (2006) Leaf surface sesquiterpene alcohols of the potato (Solanum tuberosum) and their influence on Colorado beetle (Leptinotarsa decemlineata Say) feeding. J Agric Food Chem 54:7729-7734

Szafranek B, Synak E, Waligora D, Szafranek J, Nawrot J (2008) Leaf surface compounds of the potato (Solanum tuberosum) and their influence on Colorado potato beetle (Leptinotarsa decemlineata) feeding. Chemoecology 18:205-216

Tilman D, Cassman K, Matson P, Naylor R, Polasky S (2002) Agricultural sustainability and intensive production practices. Nature 418:671-677

Tissier A, Morgan JA, Dudareva N (2017) Plant volatiles: going 'In' but not 'Out' of trichome cavities. Trends Plant Sci 22:930-938

Uematsu H, Yoshikawa K (2002) Changes in copulation and oviposition time of the diamondback moth, Plutella xylostella (Lepidoptera: Plutellidae). Jpn J Appl Entomol Zool 46:81-87

Voigt D, Gorb E, Gorb S (2007) Plant surface-bug interactions: Dicyphus errans stalking along trichomes. Arthropod-Plant Interact $1: 221-243$

Vuorinen T, Nerg AM, Syrjälä L, Peltonen P, Holopainen JK (2007) Epirrita autumnata induced VOC emission of silver birch differ from emission induced by leaf fungal pathogen. Arthropod-Plant Interact 1:159-165

Wang G, Tian L, Aziz N, Broun P, Dai X, He J, King A, Zhao PX, Dixon RA (2008) Terpene biosynthesis in glandular trichomes of Hop. Plant Physiol 148:1254-1266

Weinhold A, Baldwin IT (2011) Trichome-derived O-acyl sugars are a first meal for caterpillars that tags them for predation. Proc Natl Acad Sci U S A 108:7855-7859 
Xiao C, Liu Y, Luo S, Hua J, Liu Y, Li S (2017) Localisation of two bioactive labdane diterpenoids in the peltate glandular trichomes of Leonurus japonicus by laser microdissection coupled with UPLC-MS/MS. Phytochem Anal 28:404-409

Yarou BB, Silvie P, Komlan FA, Mensah A, Alabi T, Verheggen F, Francis F (2017) Pesticidal plants and vegetable crop protection in West Africa. A review. Biotechnol Agron Soc 21:288-304

Yoneya K, Takabayashi J (2014) Plant-plant communication mediated by airborne signals: ecological and plant physiological perspectives. Plant Biotechnol 31:409-416

Yu X, Liang C, Fang H, Qi X, Li W, Shang Q (2018) Variation of trichome morphology and essential oil composition of seven Mentha species. Biochem Syst Ecol 79:30-36
Yuan JS, Himanen SJ, Holopainen JK, Chen F, Stewart CN (2009) Smelling global climate change: mitigation of function for plant volatile organic compounds. Trends Ecol Evol 24:323-331

Zhao DF, Buchholz A, Tillmann R, Kleist E, Wu C, Rubach F, Kiendler-Scharr A, Rudich Y, Wildt J, Mentel TF (2017) Environmental conditions regulate the impact of plants on cloud formation. Nat Commun 8:14067

Publisher's Note Springer Nature remains neutral with regard to jurisdictional claims in published maps and institutional affiliations. 